\title{
IBSA: AN EMERGING TRINITY IN THE NEW GEOGRAPHY OF INTERNATIONAL TRADE
}

POLICY ISSUES IN INTERNATIONAL TRADE AND COMMODITIES

STUDY SERIES No. 35

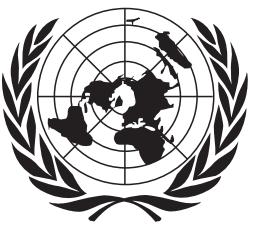

UNITED NATIONS 
UNITED NATIONS CONFERENCE ON TRADE AND DEVELOPMENT

POLICY ISSUES IN INTERNATIONAL TRADE AND COMMODITIES STUDY SERIES No. 35

IBSA: AN EMERGING TRINITY

IN THE NEW GEOGRAPHY OF INTERNATIONAL TRADE

by

\section{Lakshmi Puri}

Director of Division on International Trade in Goods and Services, and Commodities, UNCTAD

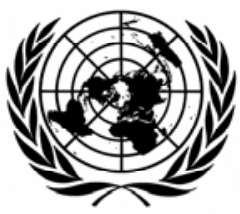

UNITED NATIONS

New York and Geneva, 2007 


\section{NOTE}

The purpose of this series of studies is to analyse policy issues and to stimulate discussions in the area of international trade and development. This series includes studies by UNCTAD staff, as well as by distinguished researchers from academia. In keeping with the objective of the series, authors are encouraged to express their own views, which do not necessarily reflect the views of the United Nations.

The designations employed and the presentation of the material do not imply the expression of any opinion whatsoever on the part of the United Nations Secretariat concerning the legal status of any country, territory, city or area, or of its authorities, or concerning the delimitation of its frontiers or boundaries.

Material in this publication may be freely quoted or reprinted, but acknowledgement is requested, together with a reference to the document number. It would be appreciated if a copy of the publication containing the quotation or reprint were sent to the UNCTAD secretariat:

\section{Chief}

Trade Analysis Branch

Division on International Trade in Goods and Services, and Commodities

United Nations Conference on Trade and Development

Palais des Nations

CH-1211 Geneva

UNCTAD/ITCD/TAB/36

\begin{tabular}{|c|}
\hline UNITED NATIONS PUBLICATION \\
\hline ISSN $1607-8291$ \\
\hline
\end{tabular}

๑) Copyright United Nations 2007

All rights reserved 


\begin{abstract}
This paper explores the opportunities for further economic cooperation between India, Brazil and South Africa in the context of the IBSA Trilateral Cooperation Forum. The IBSA integrative efforts are opening new avenues for South-South Cooperation in several areas, including on commodities, manufacturing and services exports, transport and energy issues, FDI and transfer of technology, etc. In particular, the paper looks at two tariff liberalization scenarios going beyond the minimalist preferential trade arrangements that have been agreed by IBSA countries. The CGE simulations suggest that significant trade creation gains can be reaped by all three countries. While intra-IBSA trade has tripled over the last decade, a comprehensive tariff liberalization scenario could lead to a doubling of their annual trade levels. The paper concludes with a number of policy recommendations that could help overcoming the remaining challenges for the IBSA trilateral economic cooperation.
\end{abstract}




\section{ACKNOWLEDGEMENTS}

The author is grateful to Luis Abugattas, Lucian Cernat and Sudip Ranjan Basu for their valuable inputs and suggestions during the preparation of this report. The author also wishes to thank other DITC staff who provided helpful feedback and comments on various parts of the paper. 


\section{CONTENTS}

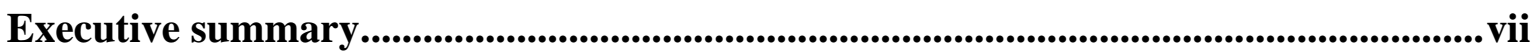

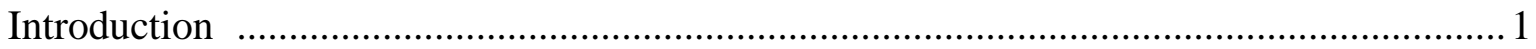

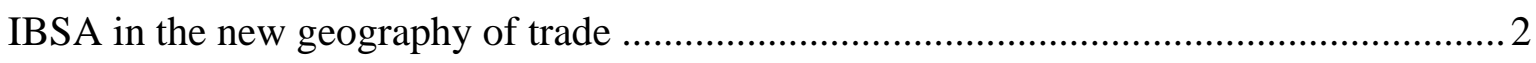

Features of a novel economic IBSA partnership ......................................................... 4

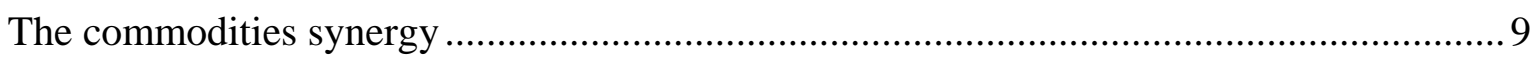

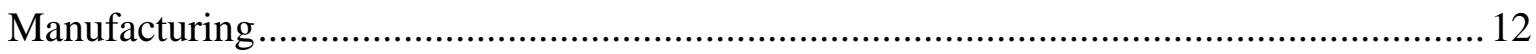

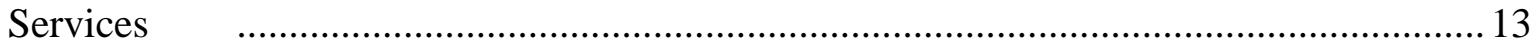

Assessing various IBSA liberalization scenarios for trade in goods ................................ 15

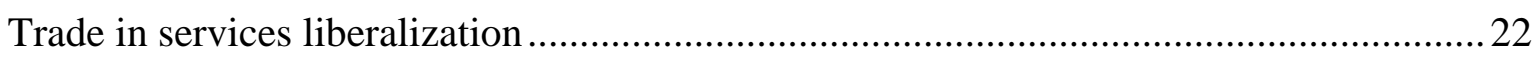

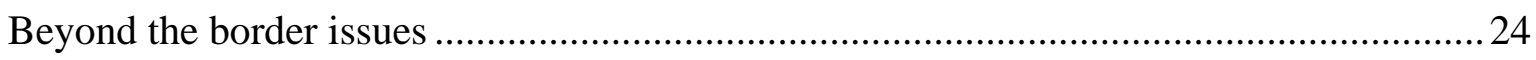

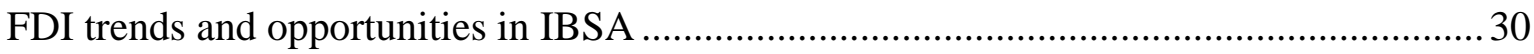

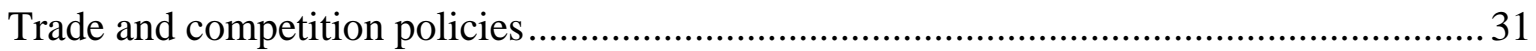

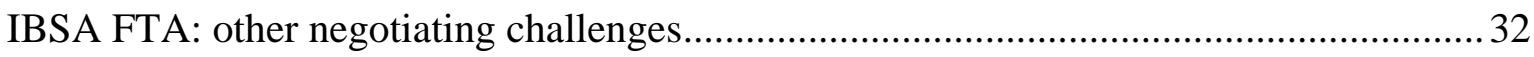

Key principles for turning challenges into opportunities ............................................ 36

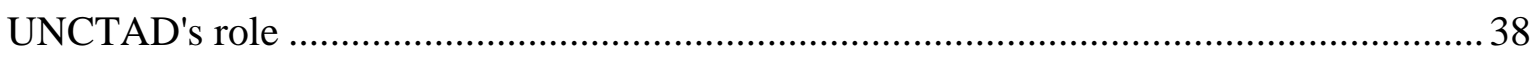

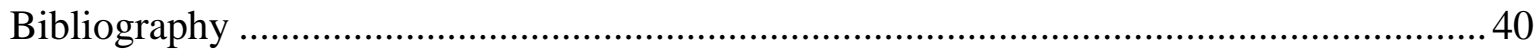




\section{$\underline{\text { List of Figures }}$}

1. Brazil: Revealed comparative advantage, by main economic sector........................ 7

2. India: Revealed comparative advantage, by main economic sector ........................ 8

3. South Africa: Revealed comparative advantage, by main economic sector............. 8

\section{$\underline{\text { List of Tables }}$}

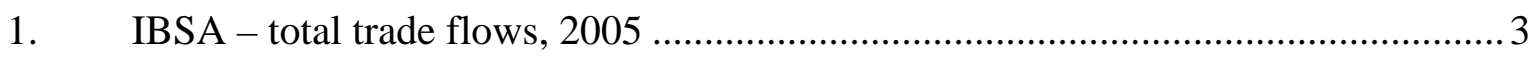

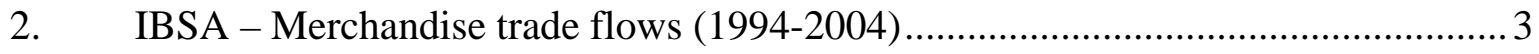

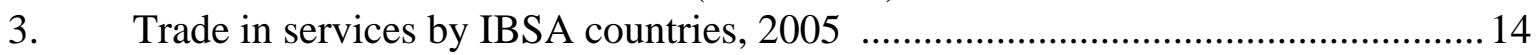

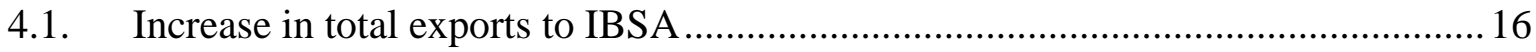

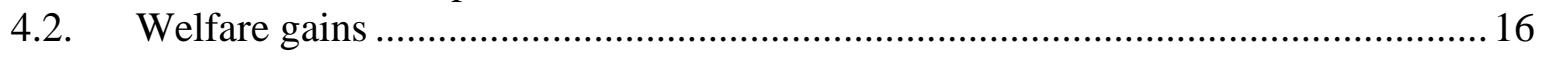

4.3. Change in demand for total unskilled labour and in output................................ 16

4.4. Increase in global exports from IBSA members................................................ 17

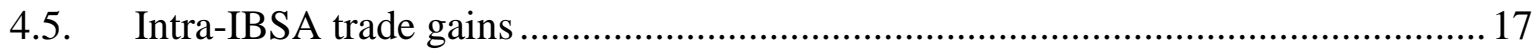

4.6. Changes in Brazil's output in full liberalization ................................................... 17

4.7. Brazil's highest export increase to IBSA partners ............................................. 18

4.7.1. Sectors in which there is an output reduction for Brazil .................................... 18

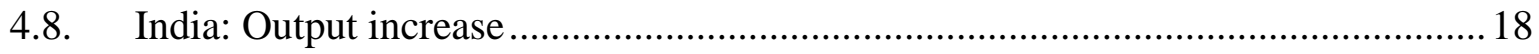

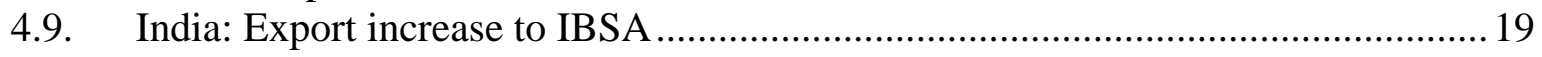

4.9.1. Sectors in which there is an output reduction for India ........................................ 19

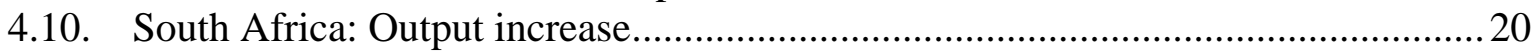

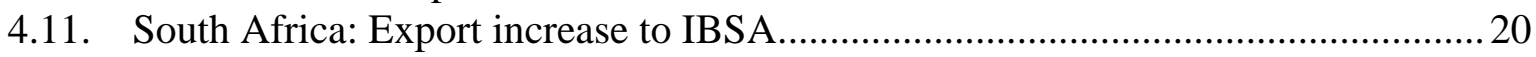

4.11.1. Sectors in which there is an output reduction for South Africa............................. 21

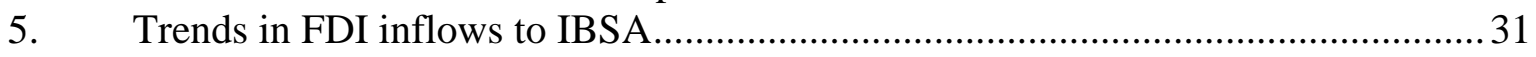

Annex table 1: Existing BTAs and RTAs under negotiation or study ...............................39 


\section{EXECUTIVE SUMMARY}

The impetus

towards deeper integration between

IBSA countries

already exists...
The IBSA

partnership exhibits some striking features of both similarity and complementarities between the three economies...
The India-Brazil-South Africa Trilateral Cooperation Forum (IBSA) was formalized pursuant to a unique initiative launched by Presidents Thabo Mbeki, Lula da Silva and Prime Minister Atal Bihari Vajpayee in 2003 at the United Nations General Assembly in New York. Unique insofar as it bought together the three large, economically wellendowed and dynamic countries from three developing continents. One of these countries is the largest economy in Latin America, another has one-fifth of the world's population and a third could act as a key engine for development in the African continent. All three have in recent years experienced rapid economic growth rates and are increasingly well integrated into the global production networks and have internationalized enterprises.

The IBSA integrative effort has raised a number of positive expectations on an economic, political and development level. Most importantly, if successful it will not only act as an excellent illustration of South-South cooperation, but each IBSA country could act as a hub for further growth and development in their respective continents.

One of the broad objectives of this paper is therefore to consider the features of this emerging IBSA trade geography. Part 2 explores existing and potential areas of synergy as well as areas of competition. The paper then attempts to draw up future projections of the impact of IBSA liberalization. These include scenarios of partial and full trade liberalization and their likely effects on sub-sectors and in terms of welfare. Part 4 considers the likely hurdles and challenges in realizing the goals the IBSA initiative may face at the national, regional and multilateral level. The paper concludes that whilst the bilateral relations between India-Brazil, India-South Africa, and Brazil-South Africa will be the building blocks of this trilateral initiative, the partnership should not just be a sum of its bilateral vectors, but should harness the synergies of trilaterally conceived IBSA projects and value additions.

The value of trade among IBSA countries has more than tripled between 1994 and 2004. This recent quantitative and qualitative increase is particularly marked when one looks at the India-Brazil trade figures and the India-South Africa trade figures, which in 2005 stood at \$2.5 billion and $\$ 4$ billion, respectively. South Africa-Brazil trade in 2004 stood at $\$ 1.5$ billion. The IBSA countries can reinforce each others economic strength by building on a market of 1.2 billion people, $\$ 1.8$ trillion of GDP and foreign trade of nearly $\$ 600$ billion. This would make the IBSA partnership of immense strategic value not only in terms of multilateral trade negotiations, but also in terms of shaping the respective roles of IBSA member countries in global economic governance. 
In terms of international trade all three IBSA countries have reached a critical mass and are now regional and global players. While each has a large and diversified economy, with competitive agricultural, manufacturing and services trade profiles they have also established distinct specializations: Brazil as an "agricultural powerhouse", India as a "services powerhouse", and South Africa has strengths in a combination of agriculture, manufacturing and services. Each country has a high technological, R\&D and human resource capacity, along with a rich mineral base.

\section{The commodities synergy}

Current trade patterns indicate both existing as well as potential complementarities in commodities, minerals, energy, industrial goods and services...
Similarities and complementarities could lead to mutually beneficial liberalization scenarios, including for dynamic sectors...
Commodities are one of the more complex, but also the most promising areas for IBSA economic cooperation. IBSA countries are major producers of soft and hard commodities - agricultural, mineral and metals - with varying levels of trade participation in these areas. For Brazil and South Africa, agricultural and mineral commodities are significant parts of their export basket, whilst for India they are mostly a steadily growing part of its import basket.

In the minerals and metals sectors, all three countries have similar endowments given their large size and prospective geography. However, opportunities for trade and investment cross-fertilization exist where certain minerals are produced in abundance in other IBSA countries. A good example would be to create synergies between the petrochemical and coal sectors between Brazil, India and South Africa. Furthermore a variable geometry could involve participation of different IBSA country in different parts of the value chain. And finally collaboration in developing and applying sophisticated technology for natural resource exploration, extraction, processing and industrial application could be beneficial to the three countries concerned.

\section{Manufacturing and services - from traditional to new and dynamic sectors}

In terms of manufacturing IBSA countries have large, diversified industrial capacities. It would appear that the three countries are competing with each other in a number of manufacturing areas, such as automotives and textiles and clothing. If we, however, consider their specialization at more disaggregated levels it becomes clear that there is considerable scope for intra-industry, as well as inter-industry trade and FDI, including in many new and dynamic sectors of world trade. Complementarities and specialization vis-à-vis each other are therefore clearly emerging. In the services area, IBSA countries are among the leading 12 developing countries which account for 75 per cent of developing country participation in international trade in services. All three have relatively evolved services economies and are active participants in trade in services. The potential for intra-IBSA services trade need to be tapped, especially in air and maritime transport services, infrastructure and commercial services. 


\section{Unleashing the energy potential}

Energy is an interesting area of collaboration among IBSA in relation to three main facets: fossil fuels (e.g. oil, gas, coal), renewable and alternative energy sources (e.g. solar, wind, hydro and nuclear power) and biofuels. All three IBSA countries are fast growing economies with large energy demands and varying domestic production and foreign dependence, particularly on fossil fuels. They also each have in varying degrees diversification programmes for alternative energy sources development and trade. All three countries have undertaken major privatization and launched public-private efforts on energy. In fossil fuels, IBSA cooperation could focus on oil shale extraction and processing, as well as "clean" coal technology. Brazil is believed to have large and as yet untapped and unutilized gas and even oil reserves which can feed India's immense appetite for oil. Furthermore, both South Africa and India can avail themselves of Brazil's expertise in deep-water oil extraction and biofuels.

\section{Trade liberalization scenarios}

A comprehensive tariff liberalization simulation using Global Trade Analysis Project (GTAP) between IBSA countries points to significant trade potential between IBSA countries. Two scenarios are considered:

While intra-IBSA

trade has tripled over the past decade, a comprehensive tariff liberalization between IBSA countries could lead to a doubling of their annual trade levels

... and the tariff revenue implications would be minimal...
Firstly, when IBSA countries liberalize vis-à-vis each other by 50 per cent (partial liberalization) and secondly, when they liberalize tariffs vis-à-vis each other to the extent of 100 per cent (full liberalization).

Trade creation gains are recorded in both scenarios, but are more significant in the case of full liberalization, where intra-IBSA trade can grow by more than 100 per cent. In view of the generally higher level of MFN tariffs of India, Brazil and South Africa tend to make more overall gains than India in the full liberalization scenario. Brazil and South Africa make some welfare gains, whilst India may have its welfare marginally decreased (-0.05 per cent) in a full liberalization scenario. The partial liberalization scenario also has its own merits, since it seems to lead to a more balanced welfare distribution among IBSA countries and vis-à-vis the rest of the world.

Ministries of Finance of countries that are about to enter FTAs often express their concerns over the possibility of revenue loss. This concern is legitimate given that Custom's duty collections still form a significant proportion of total revenue collections in developing countries. Using GTAP, in the case of a 50 per cent cut in IBSA tariffs it is found that the revenue attributable to IBSA imports declines by about 21.7 and 11.6 per cent for India and South Africa respectively. In the case of Brazil it is shown that the revenue attributable from IBSA imports rise by about 6.9 per cent. The changes in revenue are, however, extremely small in relation to the total Customs revenue collections. In India's case the revenue loss on account of a 50 per cent IBSA FTA is only about \$129 million, which is about only 1.1 per cent of total Customs revenue. 


\section{Deeper integration can have a trade and investment multiplier effect}

In today's trading environment, border issues have become less relevant when compared with other "behind-the-border" factors. In the IBSA context this would include addressing obvious trade policy instruments that may be used for protectionist purposes, both at multilateral and regional level (such as antidumping, safeguard

Deeper integration would revolve around addressing of "behind the border issues" as well as exploring crucial transport and investment...
Creating strong transport and investment links among IBSA countries is crucial... measures, countervailing duties, technical barriers to trade, Customs procedures and rules of origin), as well as other trade-related issues such as investment, competition policy, etc. The importance of addressing "behind-the-border" issues in the context of the IBSA agreement is not only to ensure institutionalized rules and where possible structures in facilitating trade, but also to tackle the very issues that can have a trade expansion effect, not just for intra-IBSA trade, but also in the context of the IBSA external trade.

\section{Improving trade, transport and FDI connectivity}

Given the distances between IBSA countries, establishing smooth connectivity through adequate and regular air and maritime transport is important. These transport linkages could be created through an increased volume of trade, more balanced trade flows, ensuring the availability of transport capacities, promoting greater competition and port efficiency, as well as the promotion of long-term arrangements between shippers and carriers. It can build on IBSA best practices and expertise, for example India's lengthy experience with railways' automation, Brazil in private participation in railways or ports, and South Africa's experience of port management.All three IBSA countries are existing destinations for FDI. Increased trade among the IBSA countries is likely to lead to increased investment flows as intra-firm trade and global production networks across IBSA are promoted. While the investment link between South Africa and India has been a more established one, investment linkages which include Brazil is a crucial supporting factor. An IBSA-wide investment promotion package may add further impetus to an already existing investment climate. One important area where further intra-IBSA investment and consolidation can be achieved is in the mineral, metal and mining sector which could benefit all IBSA countries.

\section{Guiding principles for action}

In pursuing IBSA objectives member countries will need to address a number of issues that could become significant constraints and turn these into opportunities on the basis of certain guiding principles for action:

- While the IBSA partnership will essentially be based on the building blocks of bilateral economic relations between IndiaBrazil, India-South Africa and Brazil-South Africa it is equally important that it should not just be a sum of its parts, but should harness the synergies and value added of a truly tripartite engagement. This should be done through trilateral agreements, undertakings and projects towards convergence, cooperation and collaboration. 
Many positive

possibilities yet

certain strategic

challenges have to

considered...
A big push, an early harvest, variable geometry, a "made in IBSA" logic, bold and structured cooperation and the trinity approach should be key guiding principles.
- Given relatively low levels of previous economic interaction, a big push needs to be given during this take off period, so that a critical mass of business exchanges and demonstrable winners assure sustainability of the IBSA Project. This would require launching of some high profile and viable pilot projects, such as: solar, wind, biofuels and oil shales energy, an IBSA "iron and steel" triangle, and collaboration in high-tech areas, as well as socially-relevant areas such as medicines and vaccines for tropical diseases and "living technologies" for the poor.

- In order to put behind it the history of relatively less institutionalized and structured cooperation between IBSA countries, bold and accelerated steps would have to be taken, including through more ambitious trade liberalization, facilitation, incentive-giving, rule-setting and convergencebuilding inter-governmental agreements.

- Deliberate efforts need to be made at the policy, industry and firm level, to ensure that a "made in IBSA" logic will prevail over a zero-sum view of structured trade and investment liberalization among IBSA members through more ambitious PTA/FTA approaches.

- As IBSA countries are themselves hubs of complex regional agreements and engagements, any institutionalized IBSA cooperation will have to be compatible with WTO and other existing agreements and carry SACU and MERCOSUR member along since simulations show that an IMSA (India-MERCOSURSACU) will have a net positive effect and spread the benefits amongst all members.

- A way to address some of the potential complicating factors and challenges in institutionalized IBSA cooperation is to adopt a "variable geometry" approach moving ahead in areas and among partners amenable to do so. This would avoid an IBSA process held hostage to moving on the basis of a minimum common denominator.

- Achieving an "early harvest" in those areas possible will contribute to maintaining momentum until such time that bigger steps could be taken for deeper economic integration. For example, in the context of an IMSA-PTA, the immediate elimination of nuisance tariffs would be a step in the right direction.

If all of these prerequisites are in place, IBSA countries have the necessary wherewithal to become "natural" trade and investment partners. UNCTAD, as part of its work and mandate on the "new geography of international trade" and South-South cooperation, stands ready to support and prepare the ground for such interregional initiatives among developing countries, through its research and analysis, as well as technical cooperation. 


\section{Introduction}

The India-Brazil-South Africa Trilateral Cooperation Forum (IBSA) is a unique initiative undertaken in the area of SouthSouth economic cooperation. What sets it apart is that it is a "ginger group" of three large, economically well-endowed and dynamic countries from three developing continents which are attempting to strengthen trade, investment, transfer of technology and economic cooperation among themselves. Brazil has the largest economy in Latin America, with a significant global trade presence. India, has the world's fourth largest economy in PPP terms and is also the world's second most populous country, has witnessed impressive economic and trade growth rates in the last few years. South Africa is the largest economy and trading power in Africa, accounting for biggest share of total African trade with the world.

In June 2003, the Foreign Ministers of India, Brazil and South Africa met in Brasilia, Brazil to form the India-BrazilSouth Africa IBSA Dialogue Forum. The IBSA Trilateral Cooperation Forum was formally launched by Presidents Thabo Mbeki, Lula da Silva and Prime Minister Atal Bihari Vajpayee during the $58^{\text {th }}$ session of the United Nations General Assembly in New York in September 2003. ${ }^{1}$ This forum became a formal initiative with meetings in New Delhi (March 2004), Cape Town (March 2005) and Rio de Janeiro (March 2006). The IBSA Forum laid the foundation for convergence between preferential trade negotiations of the three countries and their respective regions. The Forum also undertook to increase trade flows between the three countries to $\$ 10$ billion by 2007 and strengthen business-to-business links. In addition, the Forum undertook to continue holding IBSA business summits and conduct studies on how to increase trade and investment by establishing a Trilateral Business Council.

This paper contributes to this enquiry and effort on South-South economic cooperation. It identifies IBSA as a key formation in the new geography of international trade in which the South's role has become strong on a North- as well as South-South basis. It shows how the three countries are dynamic globally, with developing countries within their own regions, but equally inter-regionally. The exceptional growth in intra-IBSA trade in recent years is seen as a promising basis to build on more ambitious targets. It is noted that the same elements of the three countries being considered emerging economies and trading powers can also propel intra-IBSA trade, investment and transfer of technology. These include the fact that IBSA countries are influential in determining the quality, quantity and direction of international trade through their strong comparative advantages in specific areas, distinct specialization and scaling up of productive capacities. They have been incorporated into global value chains and participate in global sourcing. Many of their enterprises have become global players. The IBSA countries are leading participants in new and dynamic sectors of international trade, globally and in relation to each other. In commodities, manufacturing and services, energy, as well as technological development, although there are similarities and competitive elements, complementarities are overwhelming. This is particularly true when examined at disaggregated levels; this indicates that intra-industry trade would be as rewarding as that based on absolute comparative advantages.

\footnotetext{
${ }^{1}$ South African Government Information, Minister of Foreign Affairs, Nkosazana Dlamini Zuma, to co-chair India-Brazil-South Africa (IBSA) Forum New Delhi, India, 3 March 2004, http://www.info.gov.za/speeches/ 2004/04030416111001.htm
} 
Building on the premise of positivesum interaction and potential, it is argued that existing complementarities be fully utilized and strengthened. This will require political will and policy encouragement and facilitation on the part of IBSA governments. Meaningful mobilization of the stakeholders and civil society will be crucial to give practical momentum and sustainability to the whole process. Whilst awareness-raising and identification of opportunities and matchmaking among economic operators of the three countries on the "raison d'être" of feasible trade and investment links will be useful, some degree of structured cooperation and framework for greater economic integration will be required to nudge them into overcoming the initial hurdles and give them incentives to release the full creative energy of the IBSA trinity.

In this regard, the paper looks at two tariff liberalization scenarios going beyond the minimalist preferential trade arrangements that have been agreed by IBSA countries. Using general and partial equilibrium modelling, a full liberalization scenario (tariff removal on all goods), as well as a 50 per cent tariff cut scenario are simulated. The results suggest that there is an overall net trade-creating and welfare enhancing impact, with minimal adjustment costs involved for IBSA. The simulations also identify specific "winning" sectors and products that stand to gain the most from IBSA liberalization.

Going beyond tariffs whose relative importance is diminishing as a trade barrier, the paper examines beyond-the-border issues, trade and investment liberalization, facilitation and promotion issues which are amenable to intergovernmental agreements, both within or outside and the FTA. These include addressing rules of origin, non-tariff barriers, the challenge of standards and technical barriers, trade remedies and safeguard measures, liberalization and facilitation of trade in services, consultation and cooperation on competition policy, investment incentives, etc. The setting up and operationalization of trade logistics and transport corridors is a prerequisite, as well as a vital aspect of the IBSA project, which can only be realized through public-private partnerships.

The interface issues between a prospective IMSA PTA/FTA, i.e. the IndiaMercosur-SACU agreement, and the "spaghetti bowl" of regional trade agreements entered into by each IBSA country, as well as the WTO compatibility requirements are outlined.

In all of the areas above, the paper provides some policy options for consideration by IBSA governments and business communities, to advance the IBSA Project on an optimal path and serve the trade and development objectives of its members.

\section{IBSA in the new geography of trade}

The formation of IBSA as a platform for political consultation and economic cooperation is emblematic of what UNCTAD refers to as the new geography of international trade. ${ }^{2}$ Individually and collectively the three countries have validated the main premises of the phenomenon that has transformed the South's role and prospects in the international trading system. IBSA countries have acquired significantly increased weight and influence in international trade and economy and are contributing in an unprecedented way to its dynamism. Secondly, they are not only the engines of South-South regional trade but also interregional ones, driving as well as benefiting from, its new found robustness. Their intratrade, although still well below true potential, and small in terms of their overall trade, has been growing dramatically.

\footnotetext{
2 “Follow-up to UNCTAD XI: New developments in international economic relations” (TD/B/51/6).
} 
Table 1. IBSA - total trade flows, 2005

(\$billions)

\begin{tabular}{lccc}
\hline Country & Merchandise & Services & Total \\
\hline Brazil & 196 & 37 & 233 \\
India & 222 & 135 & 357 \\
South Africa & 119 & 22 & 141 \\
IBSA & 537 & 194 & 731 \\
\hline
\end{tabular}

Source: World Trade Report 2006, World Trade Organization.

In 2005, IBSA countries are among the top 15 developing countries, in terms of total trade. Their growing significance in international trade is shown by the way India has doubled its global trade share from 0.8 per cent in 2000 to 1.6 per cent in 2005 , amounting to total trade of $\$ 357$ billion. Similarly, in 2005 South Africa's trade grew to $\$ 141$ billion and Brazil's trade reached \$233 billion (table 1).

The value of Brazil's exports to other IBSA countries doubled between 1994 and 2004. The corresponding figures for India and South Africa are 559 per cent and 123 per cent respectively. This implies that the value of trade among IBSA's countries more than tripled from 1994 to 2004. What is significant as well is that in the period between the launch of IBSA in 2003 and
2005, intra-IBSA trade more than doubled. Thus, IBSA countries could reinforce each others economic strength by creating a market of 1.2 billion people, 1.8 trillion dollars of GDP and foreign trade of more than $\$ 730$ billion. IBSA partnership is also of immense strategic value for multilateral negotiations and shaping their respective roles in global economic governance.

There has been a transformation in the role of IBSA countries in regional and increasingly, interregional South-South trade. As table 2 shows, between 1994-2004, Brazil nearly doubled its trade with Latin America, more than tripled with Africa and more than doubled with Asia. In fact, Brazil traded more with Asia than Latin America in 2004.

Table 2. IBSA - Merchandise trade flows (1994-2004)

\begin{tabular}{|c|c|c|c|c|}
\hline Exporter & Partner & $\begin{array}{c}1994 \\
\text { Value } \\
\text { (\$mil.) }\end{array}$ & $\begin{array}{c}2004 \\
\text { Value } \\
\text { (\$mil.) }\end{array}$ & $\begin{array}{l}\text { 1994-2004 } \\
\% \text { change }\end{array}$ \\
\hline \multirow{4}{*}{ Brazil } & Latin America & 17901.7 & 33681.4 & 88 \\
\hline & Africa & 2343.4 & 10621.6 & 353 \\
\hline & Asia & 14825.8 & 34190.8 & 131 \\
\hline & World & 79066.3 & 160319.8 & 103 \\
\hline \multirow{4}{*}{ India } & Latin America & 1130.2 & 4050.3 & 258 \\
\hline & Africa & 2472.7 & 9131.3 & 269 \\
\hline & Asia & 20660.1 & 72906.2 & 253 \\
\hline & World & 54984.7 & 188110.0 & 242 \\
\hline \multirow{4}{*}{ South Africa } & Latin America & 1088.9 & 2452.2 & 125 \\
\hline & Africa & 2975.5 & 8122.5 & 173 \\
\hline & Asia & 9231.3 & 29159.4 & 216 \\
\hline & World & 46731.0 & 87997.4 & 88 \\
\hline
\end{tabular}

Source: WITS/Comtrade. 
The three countries seem to be emerging engines of not only intra- but also global and inter-regional South-South trade. The growth of interregional trade of IBSA countries is illustrative of this role and these figures suggest that IBSA project has the fundamentals in place in terms of proven capacity to enhance this role.

This growing dynamo role in intraregional and interregional South-South trade in general augurs well for IBSA trade and economic cooperation and for each country using the other partner as a gateway for intensifying intercontinental trade and investment links. That apart, in recent years, there has been a qualitative and quantitative leap in intra-IBSA trade which is particularly dramatic as between India and Brazil and India and South Africa. From a mere \$200 million in 1998 and $\$ 800$ in 2002, Indo-Brazil was $\$ 2.5$ billion in 2005 and expected to be $\$ 3$ billion in 2006. India-South Africa trade similarly has grown to $\$ 4$ billion in 2005. South Africa-Brazil trade stood at 1.5 billion in 2004. These trends indicate that IBSA is already close to the $\$ 10$ billion target set for 2007. These numbers do not fully reflect trade in service or the quantum of trade between them through third countries, nor do they factor in the major FDI proposals and joint ventures on the anvil or even in some cases the services trade that is taking place.

\section{Features of a novel economic IBSA partnership}

India, Brazil and South Africa share certain features that account for their emerging trade and development muscle and the quickening of their growth. These are and should increasingly be brought to bear on a new economic partnership among them. This partnership will essentially be based on the building blocks of bilateral economic relations between India-Brazil, India-South Africa and Brazil-South Africa. But it is equally important that the IBSA Economic Partnership should not just be a sum of its parts but harness the synergies and value added of a truly tripartite engagement. From this perspective, let us examine how their regional and global strengths can propel the IBSA Economic Partnership.

\section{Influencing changes in international trade}

It is because of the fact that Brazil, India, and South Africa have become influential players in international trade that UNCTAD is conducting analyses on the BRICS economies, including South Africa. It is noted that IBSA's evolving trade and investment punch has induced some changes in the quality, quantity and direction of international trade. Each has displayed strong comparative advantages in specific areas, distinct specialization, and scaling up of productive capacities. Thus, Brazil is regarded as an "agricultural powerhouse", India as a services one, and South Africa has a combination of strengths in agriculture, manufacturing and services. Each has a large and diversified economy, with competitive agricultural and manufacturing and services development and trade profiles. Each displays a relatively high level of technology, R\&D and human resource capacity, along with a rich mineral base. What is more, with progressive opening up to foreign trade and investment, a critical mass seems to have been reached for them to make an impact regionally and globally. This is propitious for taking IBSA trade and investment relations to new heights.

\section{Incorporation of IBSA in global value chains}

In the last few years, each IBSA country is in the process of being incorporated in some manner into global value chains in areas ranging from agrifood, minerals and metals, chemicals and pharmaceuticals, automotives, to ICT. The presence of MNCs in the commodities, manufacturing and services sectors in all three countries creates linkages within and across sectors and product areas. They foster 
complementarities, stimulate trade creation among them, and provide opportunities for moving up the value chain. Moreover, given the balance between competitive and complementarity factors in the IBSA triangle, trade-diversion and relocation of production related concerns are likely to be minimal and incorporation in global value chains result in a positive sum outcome.

\section{Participation in global sourcing}

All three countries have become important suppliers for global sourcing of goods and services. There is some overlapping but it is mostly complementary. Through the global MNCs and distribution networks, there is the positive effect of greater circulation, familiarity with, and acknowledgement of the competitiveness of each other's goods and services. At the same time, IBSA countries have become major buyers and they can become part of each other's global production chains. India and South Africa can source competitive agricultural products and ethanol, construction materials and vehicle parts from Brazil, while Brazil and South Africa can source competitive pharmaceuticals and IT-enabled services from India. Similarly, Brazil and India in turn can source competitively certain minerals and metals from South Africa.

\section{Internationalization of IBSA enterprises}

Another aspect that is crucial for IBSA enterprises, it the internationalization of Brazilian, Indian and South African enterprises, and their coming of age as regional and global operators. Some strong 'national champions' along with outwardoriented medium-sized enterprises, with the encouragement of their previously reluctant governments, are investing in other countries and continents. They have done so for locational and efficiency and market- seeking reasons, as well as for securing greater and assured access to natural and human resources, land and technologies. This gives the IBSA project the necessary entrepreneurial capacity to creatively engage in each other's production, trade and investment activities and to establish and strengthen links with counterpart national champions and outward oriented enterprises.

This is already happening. For example, Indian companies are present in South Africa in several sectors: brewing, tourism, mining and metals, vehicles, ICT. From Brazil, CVRD in minerals and metals, Odebrecht in construction and infrastructure, Marco Polo in transport vehicles, Petrobras in oil and energy, are MNCs that could profitably expand their outreach in India and South Africa. Similarly, from India, Tata in mining, minerals and metals, transport, telecommunications, and software, Ranbaxy in pharmaceuticals, OVL in oil and gas could derive benefits from operating across IBSA. Sassol in coal, AngloAmerican in mining, Old Mutual in insurance, De Beers in diamonds, MTN in telecom, are some of the South African MNCs that could bring value to trilateral IBSA trade and investment.

\section{IBSA and new and dynamic sectors of world trade}

An important dimension of IBSA countries' general trade and their intra-trade is that all three are among the top ten developing countries in terms of their participation in new and dynamic sectors of international trade, as identified and tracked by UNCTAD. ${ }^{3}$ In recent years, IBSA countries have come to play an increasing role in new and dynamic sectors of world trade. These sectors include product groups that have displayed consistently high growth and increased share in world trade, or those that are new in their export baskets. Some of the key sectors in which these

\footnotetext{
${ }^{3}$ Strengthening participation of developing countries in dynamic and new sectors of world trade: Trends, issues and policies - Background note by the UNCTAD secretariat, TD/B/COM.1/EM.26/2, December 2004.
} 
countries have registered their presence include chemicals, electrical items, automobiles and automotive parts, engines and motors, ores and metals, textiles, and certain services sectors including outsourcing.

In some of the dynamic sectors, the IBSA countries have made impressive gains worldwide. During the decade 1994-2004, for example, Brazilian world exports of mineral fuels grew by nearly 460 per cent; knitted and crocheted fabrics by 430 per cent; and aircrafts by 990 per cent. For the same period, Indian exports to the rest of the world of mineral fuels grew in value by over 1200 per cent; inorganic chemicals by 275 per cent; and optical and precision instruments by 760 per cent. Similarly, for the same decade, South Africa's export to the rest of the world of railway vehicles and rolling stocks grew in value by 600 per cent; iron and steel by 160 per cent; and organic chemicals by 380 per cent. An interesting aspect is that one of the most dynamic products in international trade, accounting for nearly \$3 trillion - electronics - the performance of IBSA countries is well below potential. They could individually and collectively see how tie-ups amongst them can enable them to more proactively participate in this important sector and trade with each other.

The principal new and dynamic product groups traded between Brazil and its IBSA partners include electrical equipments, chemicals, beverages, minerals and ores, railway vehicles and rolling stock and aircraft. The corresponding items for India are processed minerals and fuels, cereals, organic chemicals, pharmaceuticals and nuclear reactors. For South Africa, these are chemicals, mineral fuels, iron and steel, and precious stones and nuclear reactors. Some of the dynamic sectors appear to involve intra-industry trade among IBSA countries. These include certain minerals and metals, textiles, railway vehicles and rolling stocks and renewable energy products. Recent intra-IBSA FDI flows also suggest actual or potential trade among these countries in certain services sectors, including consulting and IT services.
The dynamic sectors being among the fastest growing product groups in world trade, structured and more focused collaboration among IBSA countries in these sectors at policy, industry and firm levels, and the resulting improved division of labour along the value chains, will contribute significantly to their individual and collective export dynamism and to rapidly raising their shares in world trade. As can be seen already from the composition of their trade, increased stress on these sectors, would enable them to avoid fallacy of composition vis-à-vis each other, in own and third country markets, while also contributing to strengthening participation of each in new and dynamic sectors globally.

\section{Improved terms of trade}

Trade trends indicate that India, Brazil and South Africa are profiting from increased trade with each other and will continue to do so. There are distinct improvements in their terms of trade, because they can buy and sell more competitively. Brazilian sugar and vegetable oil is cheaper for India, and Brazil gets better returns because of increased demand apart from returns from increased scale and scope from imports and exports. It is clear that this process is an account of their cost competitiveness and their complementarities and indicates that there is much greater potential for such mutuallybeneficial trade.

For example, a notable development in the last two years is the significant increase in South Africa's terms of trade, which may be extrapolated to the Indian and Brazilian experiences of diversifying markets and sources of supply to emerging developing countries, especially from other regions, and reaping terms of trade dividends. South Africa's terms of trade have improved overall, with ores and metals contributing to a large extent to these changes. Such trends would be further accentuated by regional trade liberalization. South Africa's purchasing power of exports has benefited to a large extent from India's emergence, alongside China and other Asian economies, 
as major importers of raw materials. This has led to a net rise in the demand for raw commodities such as ores and metals, translating in higher export unit prices and volumes. At the same time, South Africa has benefited from a decline in import prices of manufactures. Further, removing intra-IBSA trade barriers would also translate into lower consumer prices (in the absence of market power by exporters or importers), leading to improved consumer welfare and more competitive intermediate inputs for downstream domestic industries.

\section{IBSA complementarity- competitiveness continuum}

Patterns of competitivenesscomplementarity continuum need to be traced in commodities, manufacturing and commodities sectors. In order to go beyond superficial similarities and therefore competitive scenarios, it would be necessary to delve into specific specializations in subsectors and products differentiation at a sufficiently disaggregated level, including on account of technology development and see where complementarities exist are being exploited already.

Figures 1-3 contain revealed comparative advantage (RCA) indexes for major SITC sectors. RCAs are often used in the economic trade literature as a measure of international trade specialization. ${ }^{4}$

As expected, Brazil has a comparative advantage in animal and vegetable products, beverages and tobacco, but also in food and live animals, machinery and transport equipment and some non-fuel commodities. Brazil has a lower than unity RCA index in products like chemicals,

Figure 1. Brazil: Revealed comparative advantage, by main economic sector

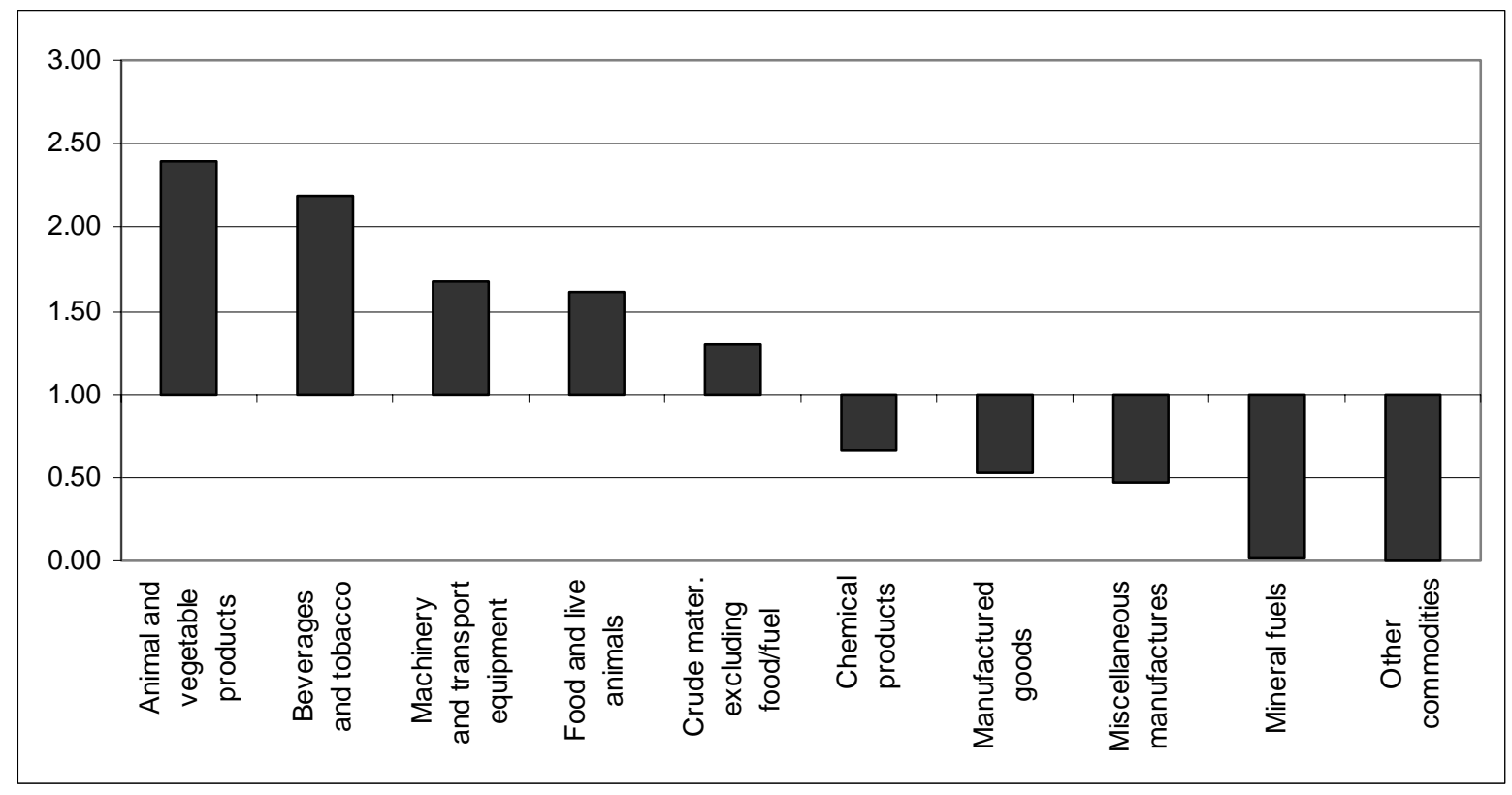

Source: Author's calculations, based on data from WITS/TRAINS.

\footnotetext{
${ }^{4}$ Several other indicators (such as distance-adjusted trade intensity indexes, intra-industry trade ratios, export similarity and complementarity indexes) could be used to assess more thoroughly the extent of current trade patterns of IBSA members. However, as argued by several authors, RCA provides a simple intuitive tool that could offer preliminary insights on trade specialization of particular trading partners.
} 
Figure 2. India: Revealed comparative advantage, by main economic sector

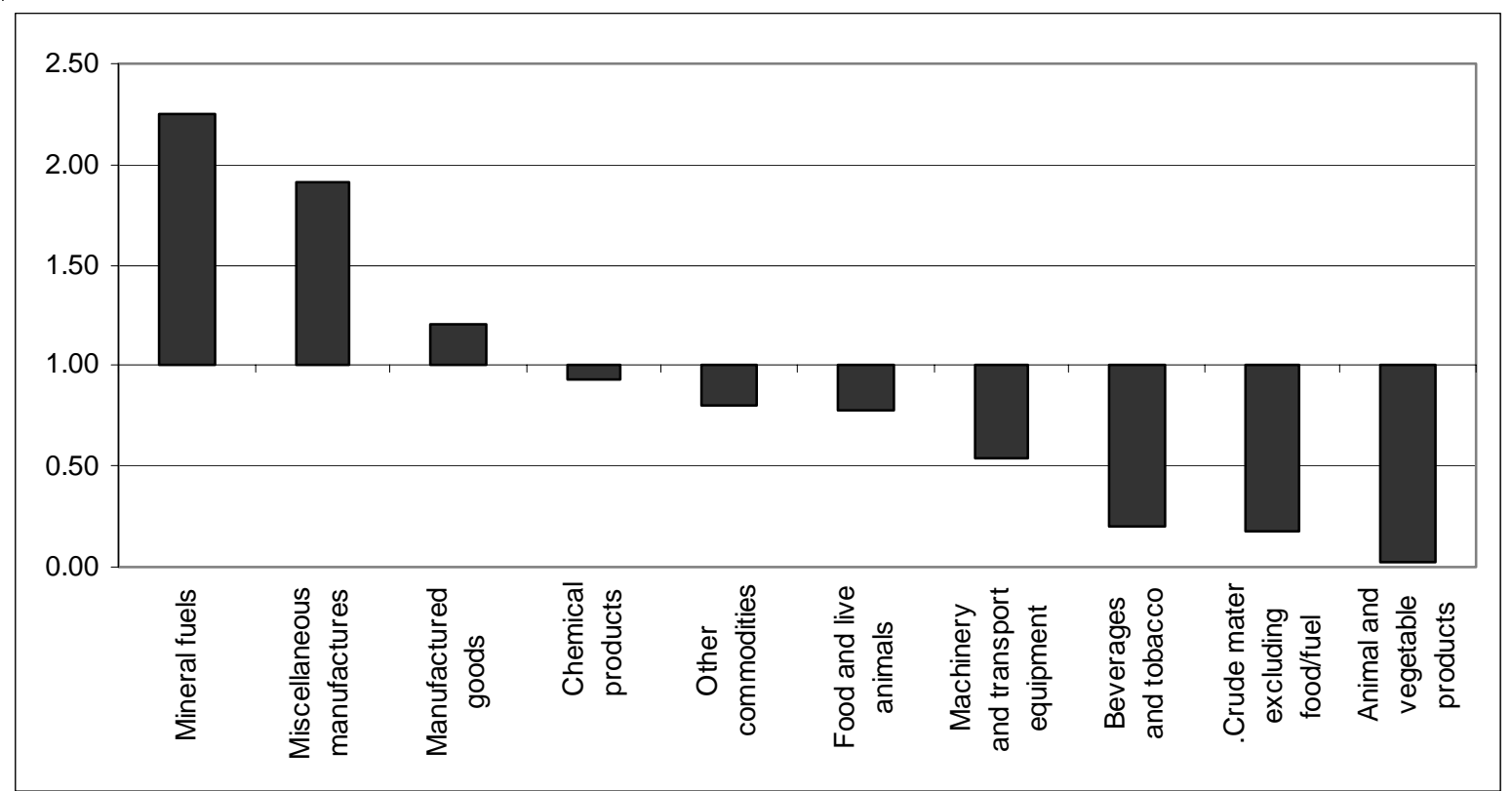

Source: Author's calculations, based on data from WITS/TRAINS.

manufactured goods, mineral fuels and other commodities. In contrast, India has a comparative advantage in processed mineral fuels and lubricants, and certain manufactured goods. South Africa has a high RCA index for commodities and crude materials other than food and fuels, as well as chemicals and manufactured goods.
Based on these rough indicators, it seems therefore that there is considerable room for a complementary integration among IBSA countries. Complementarities, extant and potential are many. The inherent cost-quality competitiveness of these countries in certain areas globally, puts them in a good position to also trade

Figure 3. South Africa: Revealed comparative advantage, by main economic sector

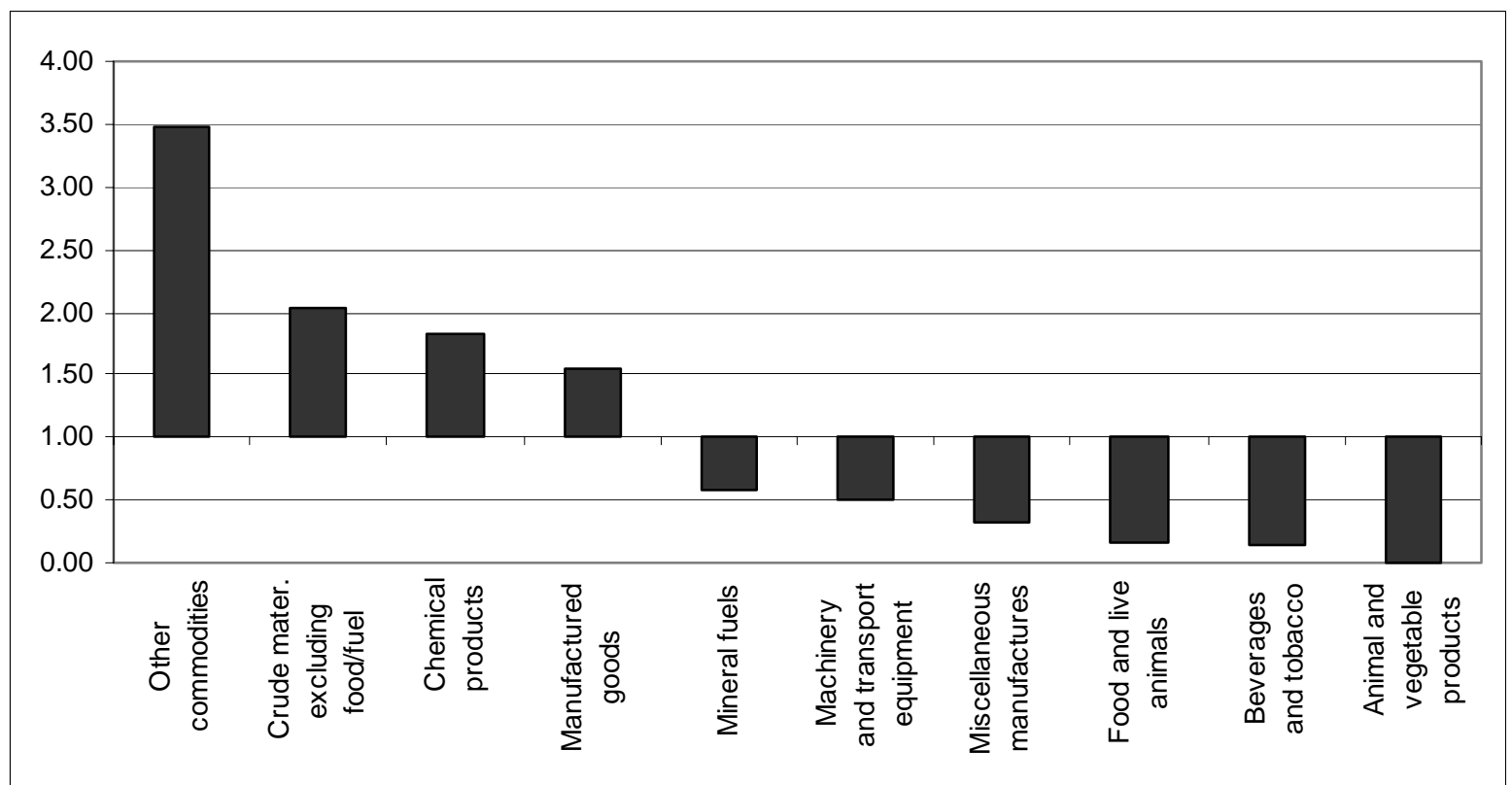

Source : Author's calculations, based on data from WITS/TRAINS. 
advantageously with each other in these areas. Each represents a large market in its own right. If there is a structured cooperation which will foster increased trade in these areas, it will deepen these competitive advantages in each of these product groups along the value chain, which, in turn, will enhance their global and South-South competitiveness.

\section{The commodities synergy}

Commodities are at one the most complex but also the most promising areas for IBSA economic cooperation. IBSA countries are all major producers of soft and hard commodities - agricultural, mineral and metals - with varying levels of trade participation in these areas. For Brazil and South Africa, agricultural and mineral commodities are significant parts of their export basket, whilst for India, they are mostly a steadily growing part of its import basket. Each country is a substantial agricultural producer in the world, but the patterns of agricultural trade differ among them and throw up possibilities for expanding existing trade flows in certain agricultural commodities and in opening up significant new trade in certain other products.

India is a large producer of wheat, sugar, tea, spice, rice, lentils, dairy and cotton but commercial exports are constrained by ever growing domestic demand, shrinking arable land, need to keep the food prices affordable for poorer consumers and to support subsistence farmers. So in the short term, it will tend to maintain some trade barriers on agricultural products but in the medium to long term, it will be importing substantially increased volumes and values of sugar, vegetable oil, lentils, and even cereals like wheat. At the same time, with growing purchasing power of its huge population there is growing demand for higher value and processed agricultural products ranging from diary, meat, fresh vegetables and fruits, beverages, including juices and coffee. India's agricultural exports include rice, tea, spices, marine products, horticultural products and wheat and processed foods.

Agriculture is Brazil's strong suit with almost limit-less availability of arable land and water, high agricultural productivity and competitive capacity in transport, storage, distribution and logistics for agricultural exports. Brazil's exports amounted to $\$ 118$ billion in 2005 and are growing. It is among the world's largest producers of sugar, soy beans, soybean oil, coffee, maze, orange juice, beef, poultry and cotton. It is also a net importer in a major way of foodstuffs including wheat flour, rice, frozen fish and dairy products, amounting to $\$ 73$ billion 2005 .

South Africa, another significant agricultural exporter, is the largest supplier in Africa. It has comparative strengths in wheat, beef, dairy, fruits and vegetables, horticulture and marine products. With strong vertical integration linkage with developed-country producers and retailers, its agricultural exports are largely destined to the markets in the EU-25, but the destinations are diversifying increasingly.

Deriving from this, there is a significant potential for increasing bilateral agricultural trade among the three, as well as trilateral intra-agricultural industry trade. For instance, India will be a major importer of sugar, soy beans and soybean oil whilst also incrementally absorbing coffee, poultry and beverages from Brazil. South Africa can look to export opportunities in dairy, wheat flour, coarse grains and processed products to India and additionally fishery products to Brazil. India can potentially increase its exports of rice, tea, spices and processed products to these countries. With respect to intra-industry trilateral trade, areas, such as cotton suggest themselves. Both India and South Africa import cotton from Brazil, while South Africa at the same time exports cotton to India. India in return exports cotton yarn and fabrics to these two countries. This trade matrix may signify existing product differentiation. 
In addition, cooperation among three nations in the areas of $R \& D$ in biotechnology, bio-safety, standard - setting and certifications - such as the cooperation taking place between the India Council of Agricultural Research (ICAR) and EMBRAPA - cannot only enhance trade among themselves, but can also further lift up their basic supply capacity vis-à-vis the world market.

In the minerals and metals sectors, all three have similar endowments. With their large size and prospective geography, they are good places for a variety of mineral resources in substantial quantities. They possess strong technological expertise in extractive and mining areas, and several able domestic companies are major actors in global markets. All three countries have large, growing, domestic markets for minerals and metals raw materials. Further, they all seek to have integrated production and entire value chains, where possible. This scenario contains several opportunities for trade and investment cross-fertilization, such as:

Where different minerals are produced in abundance in other IBSA countries, but are either not there in own country or the demand is so great that there is still a requirement to import from abroad, the trade and investment opportunities are tremendous and are being prospected and utilized. For instance, South Africa could provide ferro-alloys, manganese, chromium and vanadium to other downstream steel producers in India and Brazil, at a time when there is considerable demand growth, particularly from China.

Where different types or specificities of the same minerals/ores are present but needed by the other for reasons of processes used or energy or environmental reasons. For instance, this could be promoted in the petrochemical and coal sectors between Brazil, India, and South Africa.
Where a variable geometry involving participation of different IBSA countries in various parts of the value chain, depending on the competitive advantage of enterprises and human resources and special attributes of those resources can bring synergy, there is room for increased trade and investment. Diamonds, precious and semi-precious stones, gold and platinum found mainly in South Africa and Brazil, but also in India, are good examples. Diamonds and gems are cut competitively in India, whilst setting and jewellery making of different types is carried out in all three countries.

Where collaboration in developing and applying sophisticated technology for natural resource exploration, extraction, processing and industrial application can be beneficial. For example, high-tech iron ore and gold extraction, beneficiation methods, smelting, clean coal, liquefied coal technology and oil shale processing and extraction can be developed and shared among IBSA countries, or even as IBSA projects or with appropriate participation of global MNCs.

Overall, if these three countries want to maintain their leadership and competitive edge in this domain, they should encourage collaborative efforts in this area, with a particular emphasis joint $R \& D$ projects, as well as transfer of technology. FDI in this sector will play a crucial role in moving this cooperation forward as will facilitative policies in mineral and mining sectors. In some cases, it could be advantageous for IBSA mineral companies to join hands in acquiring assets and locating in third country markets, regionally and interregionally in the context of intensifying competition for natural resources. 


\section{Energy sector cooperation}

Energy is an interesting area of collaboration among IBSA in relation to three main facets: fossil fuels (e.g. oil, gas, coal), renewable and alternative energy sources (e.g. solar, wind, hydro, nuclear) and biofuels (e.g. biodiesel and ethanol from biomass). All are fast growing economies with large energy demands and varying domestic production and foreign dependence on fossil fuels along with diversification programmes for alternative energy sources development and trade. All three countries have undertaken major privatization and launched public-private efforts on energy. These include the biofuel/ ethanol programme in Brazil, attempts to build industrial clusters around coal resources in South Africa and India, government-supported incentive programmes for wind and solar energy, supporting new commercially viable, energy and environment-efficient technologies for exploration, extraction and processing of fossil fuels.

On fossil fuels, cooperation between India and South Africa will be important to enable India to make full use of its vast coal reserves which already provide 56 per cent of its commercial energy supply. South Africa' Sasol is the world's largest manufacturer of oil from coal, gasifying the coal and then converting it into a range of liquid fuels and petrochemical feedstocks. As between India and Brazil, collaboration has already started in terms of trade and investment in the oil and gas area and Brazil is believed to have large and as yet untapped and unutilized gas, and even oil reserves which can feed into India's exponential appetite for oil imports. Deep-water oil extraction is another area of Brazil-India cooperation. Petrobras is considered a leader in deep-water production technology and continues to expand crude oil output largely thanks to the production of offshore wells. There are also tripartite opportunities for collaboration in as yet to be developed areas with tremendous potential for all three countries such as oil shale extraction and processing. ${ }^{5}$

Each has invested considerably in hydropower projects, big and small, and is seeking to develop this further. Brazil's dependence on hydropower is to the extent of 90 per cent and India too is looking to tap its hydropower resources to the maximum. South Africa is mainly focussed on small hydropower projects. There is thus considerable scope for exchange of experience, trade in hydropower equipment and technologies among IBSA in this area.

India's wind energy potential is rated the third largest in the world, only after Europe and US, both producing and exporting wind turbines. Another growing market is Brazil, with a sizable wind potential. The federal government has created an incentive programme, called Proinfa to build new production capacities of renewable energy for 2008. The programme seeks to produce 10 per cent of Brazilian electricity through renewable sources. As from 2003, South Africa has also begun to take steps to promote wind energy. Technological cooperation and trade in wind energy equipment and installation can therefore be a major IBSA project. IBSA countries also have civilian nuclear energy programmes which are being strengthened and which also provide commercial opportunities.

Solar energy can be the basis of tripartite cooperation in technology development and transfer, production and trade, as all three countries have abundant sunshine all-year-round. Fortunately, IBSA countries have developed significant capacity in photovoltaics, solar cooking, heating and lighting devices and power generation through research, development and private-public partnerships. In fact, solar energy is an ideal candidate for an IBSA project which could be launched with the support of the three governments and with the involvement of key private sector actors in these countries. Recent

\footnotetext{
${ }^{5}$ For an account of India's reserves of oil shale and potential oil production, see for instance "Enough shale oil to join OPEC? “ The Times of India, 14 August 2005.
} 
technological breakthroughs in solar panels by South Africa and work required and being done in India and Brazil to produce third-generation high-efficiency solar devices using nanotechnologies, photonics, optical meta-materials, plasmonics and semiconductor polymer sciences, all offer the prospects of cost-effective new technologies which can be implemented across IBSA countries.

Growing concerns about petroleum price fluctuations, energy independence and the environmental ramifications of fossil fuel use have drawn substantial attention to biofuels as an alternative to meeting the world's growing energy demand. Brazil has been a pioneer and commercialization of biofuels, bioethanol, biodiesel, and more recently H-bio - for use particularly in the transportation sector. India has recently turned to biofuels to meet a significant fraction of its energy needs and set ambitious targets, replicating the Brazilian experience. While India will be using Jatropha - a plant originally taken by the Portuguese from Brazil to India - for their biodiesel programme, ethanol is being produced in India from sugarcane molasses and therefore competes with food and other uses for sugar in the context of land scarcity. India has already started importing significant volumes of ethanol from Brazil to meet its blending targets and this represents a major area of trade between India and Brazil. South Africa has a nascent biofuels market and production capacities are being developed from both sugar and maize and is involved in developing projects such as EthanolAfrica. Therefore, there will be major trading opportunities for Brazil in South Africa, but also for India not only in biofuels but also associated technologies, including flex-fuel technology (UNCTAD, 2006).

\section{Manufacturing}

The large, diversified industrial capacities and complementarities and specializations of IBSA countries vis-à-vis each other are clearly emerging. India is strong in both lowest cost labour intensive products, low to medium tech goods as well as high tech goods. Promising export areas to Brazil and South Africa range from pharmaceuticals, chemicals and petrochemicals, textiles and clothing, agricultural equipment, automotives, rail equipment, engineering goods, leather goods, steel and steel products, power transmission and distribution equipment, automation products, telecom equipment, medical electronics, gems and jewellery, etc.

The scope for exports from Brazil to other IBSA countries in manufacturing areas range from chemicals and petrochemicals, minerals and metals such as copper and iron ore products, steel and steel products, building materials, textiles and clothing, leather and leather products, agroprocessing, rubber and rubber products, pulp, paper and wood products, motor vehicle and parts and electronics and aircrafts. South Africa's exports could be in areas ranging from agro-processing, wood and wood products, transport equipment, fertilizers, mining equipment, railway rolling stock, automotives, chemicals, ICT and telecommunication hardware, metal products, textile, clothing and footwear.

It would appear that the three countries are competing with each other in a number of manufacturing areas such as automotive and transport, textile, clothing and leather, chemicals. But looking at their specialization at more disaggregated levels it becomes evident that there is considerable scope for intra-industry as well as inter-industry trade and FDI, both for market and efficiency seeking and strategically locating to sell reasons. As pointed out in the economic literature, in any FTA scenario, increased intra-industry trade provides an insurance for a win-win outcome and lower adjustment costs.

Finding complementarities of the textile industry in the three countries is a case in point. All three countries have a significant integrated production capacity in this sector, with India taking the lead in scale, scope and value of production, but most importantly in trade. India's exports in the post-ATC era have gone up and in 
2005-2006 fiscal year Indian textile and clothing exports were $\$ 17$ billion, of which $\$ 8.2$ billion accounted for by garments. This is set against the $\$ 1.5$ billion textile and clothing exports of Brazil and $\$ 600$ million of South Africa in 2004. All three countries have relatively higher tariff barriers in this sector. However, an analysis at SITC 4 and 5-digit level indicates many complementarities between the products of India, Brazil and South Africa. The latter two can and have moved into niche areas which may be different from those of India and which can then provide increased opportunities for intra-industry trade for the sector. As already noted, textiles and garments, despite the fallacy of composition in certain product lines, is a perennially dynamic sector with new product groups emerging, with increased use of textiles in non-traditional areas such as construction, sports, agriculture, transport, packaging and medical sector. High-end textiles and garments also presents areas of complementarity, including in relation to designing and ethnic textiles. Furthermore, big manufacturers including in India can benefit from the trend towards outsourcing of input supplies to specialized "boutique" suppliers in Brazil and South Africa and vice-versa, as another way of benefiting from increased trade and investment in the IBSA region.

\section{$\underline{\text { Services }}$}

In the services area, IBSA countries are among the leading 12 developing countries accounting for 75 per cent of developing country participation in international trade in services. All three have relatively evolved services economies and are active participants in trade in services. According to UNCTAD's latest estimates (2005), India's total trade is $\$ 306.8$ billion, of which goods and services trade contributed about $\$ 217.1$ and $\$ 89.6$ respectively. India has emerged as one of the fastest growing exporters of services. The share in the world service exports has gone up to 2.8 per cent in 2005 from 1.9 per cent in 2004. The share of services in India's total trade also rose from 29.1 per cent in 2004-2005 to 35 per cent in 2005-2006. In 2005, Brazil recorded exports of commercial services of $\$ 15$ billion and 22.2 billion of imports. South Africa exported $\$ 10.2$ and imported $\$ 11.9$ billion worth of services trade. However, since then all three countries have surged ahead with high growth rates. These patterns demonstrate how all three countries are growing very fast in this dynamic sector of international trade. This, combined with the sheer magnitude of their services trade, provides a good indication of the enormous trade potential that the IBSA initiative could unleash. Not only is there value in terms of their own export capacity and domestic market but each has a prominent regional position, offering the other IBSA partners the possibility of acting as regional services hub.

The category of "other commercial services" is currently the most dynamic segment of trade in services, comprising a wide variety of services activities. ${ }^{6}$ Both Brazil and India are becoming strong international players in this segment of trade in services. In the case of India 74.4 per cent of total services exports is in this dynamic category and in the case of Brazil 51 per cent of total services exports. Imports of these services are respectively 52.6 per cent in the case of India, and 54.5 per cent for Brazil. South Africa presents a portrait of a services export structure similar to that of most developing countries in which the bulk of its services exports is accounted for by transportation and travel, while other commercial services accounts only for 11.8 per cent of total services exports, and 21.9 per cent of total imports. The strengths of individual IBSA countries in different services sectors and subsectors point to many complementarities and potential for trade creation through all 4 modes of service delivery. This is not only in respect of sectors, but niches within sectors, mirroring intra-industry trade in the case of goods.

\footnotetext{
${ }^{6}$ Includes the following items: construction, insurance, financial services, computer and information services, personal cultural and recreational services, other business services, and royalties and licenses fees.
} 
Table 3. Trade in services by IBSA countries, 2005 (\$billion) - BOP statistics

\begin{tabular}{lccc}
\hline & Exports & Imports & Total trade \\
\hline India & 50.0 & 39.6 & 89.6 \\
Brazil & 15.0 & 22.2 & 37.2 \\
South Africa & 10.2 & 11.9 & 22.1 \\
Total IBSA & 75.2 & 73.7 & 148.9 \\
\hline
\end{tabular}

Thus, for example, India's emerging services powerhouse status is largely derived from the global competitiveness of its ICT-enabled services and is already looking to South Africa and Brazil as important nodes in its ICT globalization strategy. Moreover, as India moves up the value chain, it is increasingly offshoring and both Brazil and South Africa represent attractive and ready-made platforms in themselves and regionally. Business and professional services, high-end health services and educational services, particularly related to ICT and related engineering services are some of the other of India's strengths that Brazil and South Africa could tap into through trade and FDI.

Brazil has become a global player in consulting, engineering and construction services. Large Brazilian firms as $\mathrm{N}$. Odebrecht, Camargo Correa and Andrade Gutierrez, among others, have a long history of very active participation in the world market for these services competing with success with developed countries firms. Brazil has also developed competitiveness in services incidental to the oil industry due to its Petrobras complex. Furthermore, Brazil is in a good position to provide services related to agriculture, and also a myriad of specialized professional services to the other IBSA members. Brazil also could significantly contribute with the financial integration of IBSA through the expansion of its financial services companies in the region.

South Africa has the most advanced, banking and insurance systems in subSaharan Africa, and play a major role in the region and portrays international levels of competitiveness. There is potential for expanding the activities of South African financial services firms in Brazil and India.
In fact, financial and insurance services have been pioneering South African investments especially in India, but also in Brazil. South Africa also has a well developed distribution service sector, and has wholesale and retailing firms which are very active in Africa, and also with investments in India as is the case of Shoprite. A niche of potential advantage for South Africa rests in mining services that have evolved on the basis of the country's resource endowments. According to a survey, South African companies have identified potential opportunities in Brazil and India in the following services sectors: financial services, tourism, information and telecommunications technology, education and training, health, film-making and entertainment services (Soko, 2006).

Cultural and entertainment services represent a lucrative area of intra-IBSA trade and collaboration. In this field, the three have remarkable regional and global capacity and outreach, including in its linkage to the ICT sector and uniqueness of cultural products offered. In addition, India is the world's largest film producer with strong capacity in TV programme and music production, whilst Brazil and South Africa both have strengths in TV programme and music. There are four types of actions that could be explored. One is opening the IBSA market for production of audiovisuals and cultural expressions in the more general sense. Secondly, collaborative efforts for joint productions and distribution of IBSA products in each other's markets and in third markets, particularly regional. Thirdly, each could share its technological capabilities. For example, India could provide production-related IT software for audiovisuals. Fourth, promotion of cultural performances and troupes and other cultural products could be encouraged, 
including through the provisions of special facilities by host governments. Progress in this area would not only contribute to closing the cultural gap have positive spillovers in the economic area.

A similar effect would be achieved by upgrading trade and investment in tourism services among IBSA countries. Up to now, none of the three countries figures among the main tourism destination or source countries of each other. Whilst there have been considerable improvements in IndiaSouth Africa tourist flows, India-Brazil flows are hampered by high travel costs and availability of frequencies. Heightened mutual awareness, including on account of IBSA partnerships, could create sufficient incentives for both private sector and governments to implement the measures needed for increasing tourism flows across IBSA. Implementation of the IBSA Air Transport agreement would contribute in achieving this objective.

\section{Assessing various IBSA liberalization scenarios for trade in goods}

The tariffs in IBSA countries are generally high, compared to current levels. However, each has been undertaking significant autonomous liberalization and applied rates have declined considerably in recent years. Furthermore, Brazil, South Africa and now previously reluctant India, are at the core of several trade agreements that have shaped trading relations in their respective continents. Each IBSA country is entering into new regional trade negotiations (see Annex table 1). The three major emerging economies of the South have few FTAs with developed countries. Only South Africa has one such operational agreement with the EU. All three countries have examined the feasibility and/or conducted trade negotiations with developed countries. Brazil is engaged in the FTAA process or through MERCOSUR with the EU. South Africa through SACU is negotiating with the US, Canada and EFTA. Even India is examining the possibility of an FTA with Japan. Most of these negotiations, however, seem to have slowed down owing to disagreements over various aspects. This has added impetus to the IBSA countries in moving ahead at full speed to conclude trade agreements with other developing countries, and thus the excitement and support for a possible IBSA PTA leading to an FTA assumes some importance.

Despite the initiation of IBSA in early 2003, there have been only few concessions exchanged between its members, and their trade is mostly conducted on an MFN basis under the WTO. Any IBSA PTA or FTA would have to take into account the extent of MFN liberalizations in areas of each other specialization that could result from the ongoing Doha negotiations in agricultural and non-agricultural market access. As members of the GSTP (Global System of Trade Preferences) India and Brazil, have exchanged tariff concessions in a limited way and are engaged in market access negotiations in the context of the third round of GSTP, which is serviced by UNCTAD, and which is scheduled to be concluded by December 2006. ${ }^{7}$ The two countries are key, along with other partners such as Argentina, to having an optimal package of market access and rules of origin for a new GSTP that delivers on its promise of substantial South-South liberalization. As part of IBSA cooperation South Africa's joining the GSTP agreement would also add weight.

Moreover, Brazil and India have also liberalized about 450 product lines under the India-Mercosur PTA agreed in March 2005. India is negotiating with SACU to establish a PTA and MERCOSUR and SACU have finalized negotiations on a PTA on a longer list of products than IndiaMERCOSUR PTA. A preliminary analysis indicates that much more will have to be put in any IBSA liberalization basket in order to capture the products of high specialization of IBSA partners and result

\footnotetext{
${ }^{7}$ For further details on GSTP negotiations, see the UNCTAD website (www.unctad.org).
} 
in significant trade creation. Hence, meaningful access in products beyond the present PTAs should be considered for scheduling, even if a more ambitious FTA is not immediately envisaged. Moreover, deeper tariff cuts than presently provided by the existing PTAs would need to be undertaken.

\section{a. General equilibrium simulations}

A comprehensive tariff liberalization simulation using GTAP between IBSA countries also points to significant trade potential between IBSA countries. Two scenarios are considered: Firstly, when IBSA countries liberalize vis-à-vis each other by 50 per cent (partial liberalization) and secondly, when they liberalize tariffs vis-àvis each other to the extent of 100 per cent (full liberalization).

Gains are recorded in both scenarios but are more significant in the case of full liberalization. In view of the generally higher level of MFN tariffs of India, Brazil and South Africa tend to make more overall gains than India in the full liberalization scenario. Intra-IBSA trade can grow by more than 100 per cent in a full liberalization scenarios (see table 4.1). Though the welfare results for India appear to be negative in full liberalization (table 4.2), it is important to note that total output and total demand for unskilled employment in India tend to remain unaffected (table 4.3).

From the results included in table 4.2. one could infer that the partial liberalization scenario has nevertheless its own merits, since it seems to lead to more balanced welfare distribution, such as:

- a minor global welfare gain improvement (as opposed to \$357 million losses worldwide in the full liberalization scenario);

- positive welfare gains for all IBSA countries (as opposed to $\$ 340$ million losses in India);

Table 4.1. Increase in total exports to IBSA (in per cent)

\begin{tabular}{lcc}
\hline & Partial liberalization & Full liberalization \\
\hline Brazil & 53.99 & 186.30 \\
India & 25.09 & 70.43 \\
South Africa & 43.74 & 107.08 \\
IBSA Total & 40.24 & 111.71 \\
\hline
\end{tabular}

Table 4.2. Welfare gains, in \$millions

\begin{tabular}{lcc}
\hline & Partial liberalization & Full liberalization \\
\hline Brazil & 125.61 & 414.54 \\
India & 4.53 & -339.35 \\
South Africa & 227.50 & 504.67 \\
Rest of world & -348.05 & -936.97 \\
Total global & 9.59 & -357.11 \\
\hline
\end{tabular}

Table 4.3. Change in demand for total unskilled labour and change in output

\begin{tabular}{lccccc}
\hline & \multicolumn{2}{c}{ Unskilled labour demand (in per cent) } & & \multicolumn{2}{c}{ Output (in per cent) } \\
\cline { 2 - 3 } \cline { 5 - 6 } & Partial & Full & & Partial & Full \\
\hline Brazil & 0.000008 & 0.000008 & & 0.02 & 0.07 \\
India & 0.000000 & -0.000007 & & 0.02 & 0.06 \\
South Africa & 0.000025 & -0.000025 & & 0.10 & 0.23 \\
IBSA Total & 0.000006 & -0.000003 & & 0.03 & 0.08 \\
\hline
\end{tabular}


Table 4.4. Increase in global exports from IBSA Members, in per cent

\begin{tabular}{lcc}
\hline & Partial liberalization & Full liberalization \\
\hline Brazil & 0.07 & 0.16 \\
India & 0.52 & 1.83 \\
South Africa & 0.01 & 0.21 \\
IBSA Total & 0.23 & 0.82 \\
\hline
\end{tabular}

Table 4.5. Intra-IBSA trade gains, in per cent

\begin{tabular}{lcccc}
\hline & \multicolumn{4}{c}{ Export destination } \\
\cline { 2 - 5 } Exporting countries & Brazil & India & South Africa & IBSA Total \\
\hline Brazil & 48 & 284 & 84 & 186 \\
India & 45 & 121 & 125 & 70 \\
South Africa & 48 & 126 & & 107 \\
IBSA Total & & 97 & 112 \\
\hline
\end{tabular}

- only one-third of losses that occur would to the rest of the world under the full liberalization scenario.

Despite securing the least intra-IBSA trade gains, India makes the most significant gains in terms of its global exports, which rise by nearly 2 per cent. Thus full IBSA liberalization appears to offer significant global competitiveness gains for India (see table 4.4).

\section{Regional trade gains}

Table 4.5 shows the bilateral export gains between the IBSA countries. The variance is as large as a near 300 per cent increase in Brazil's exports to India to a 45 per cent increase in South Africa's exports to Brazil. In terms of growth in regional trade Brazil tends to be the best performer, followed by South Africa and India.
Country specific results for the full liberalization scenario are presented below.

\section{Brazil}

Gains to Brazil appear to be singularly attributable to production responses in agriculture, particularly the vegetable oils sector. This is in large measure due to Brazil's competitiveness in this sector, and also the high level of demand in India.

Brazil's highest export increase to IBSA partners is recorded in the case of sugar, vegetable oils and beverages (see table 4.7). In the manufacturing sector it makes gains in the case of motor vehicles, textiles and leather products (which include shoes).

Brazil is, however, likely to see output and employment decreases in the case of non-ferrous metals, wheat, leather and meat products.

Table 4.6. Changes in Brazil's output in full liberalization

\begin{tabular}{lc}
\hline Winning sectors & $\begin{array}{c}\text { Output increase } \\
\text { (in per cent) }\end{array}$ \\
\hline Vegetable oils and fats & 17.16 \\
Oil seeds & 4.94 \\
Wool, silk-worm cocoons & 3.09 \\
Motor vehicules and parts & 1.69 \\
Plant-based fibres & 0.10 \\
\hline
\end{tabular}


Table 4.7. Brazil's highest export increase to IBSA partners

\begin{tabular}{lc}
\hline Winning sectors & $\begin{array}{c}\text { Export increase to IBSA } \\
\text { (in per cent) }\end{array}$ \\
\hline Sugar & 3921.05 \\
Vegetable oils and fats & 635.20 \\
Beverages and tobacco products & 606.25 \\
Wool, silk-worm cocoons & 339.07 \\
Motor vehicules and parts & 288.59 \\
Bovine meat products & 216.67 \\
Manufactures & 179.30 \\
Textiles & 176.53 \\
Meat products & 172.16 \\
Crops & 167.04 \\
Leather products & 144.99 \\
Metal products & 134.55 \\
Electronic equipment & 124.57 \\
Mineral products & 112.43 \\
\hline
\end{tabular}

Table 4.7.1. Sectors in which there is an output reduction for Brazil

\begin{tabular}{lc}
\hline Sector & $\begin{array}{c}\text { Ouput decrease } \\
\text { (in per cent) }\end{array}$ \\
\hline Metals & -1.64 \\
Wheat & -1.46 \\
Leather products & -1.39 \\
Meat products & -0.98 \\
Wood products & -0.94 \\
Transport equipment & -0.87 \\
\hline
\end{tabular}

\section{India}

India's output response is highest in the case of meat products (mainly poultry) and wearing apparel. These sectors are presently highly protected in Brazil and South Africa. The output gain of 2.7 per cent in the wearing apparel sector results in an approximately similar increase in the demand for unskilled labour in India. An IBSA arrangement also generates significant positive production responses in the electronics/machinery equipment sectors.

Table 4.8. India: Output increase

\begin{tabular}{lc}
\hline Winning sectors & $\begin{array}{c}\text { Output increase } \\
\text { (in per cent) }\end{array}$ \\
\hline Meat products & 8.13 \\
Wearing apparel & 2.70 \\
Manufactures & 1.64 \\
Machinery and equipment & 1.29 \\
Electronic equipment & 0.92 \\
Metal products & 0.74 \\
Mineral products & 0.66 \\
Transport equipment & 0.62 \\
Textiles & 0.53 \\
Leather products & 0.42 \\
\hline
\end{tabular}


The costs of full liberalization will be most acutely felt by the oilseeds and vegetable oils sector. In the case of vegetable oils, output and demand for unskilled labour decline by about 7 per cent. The sharp decline in output of vegetable oils needs to be taken into account given that even as of now food security in edible oils is highly import dependent. While non-ferrous metals sector shows a decline in output, this may not be a cost to the overall economy, as it may allow cheaper imports of the same and make the downstream Indian manufacturing more competitive.

Table 4.9. India: Export increase to IBSA

\begin{tabular}{lc}
\hline Winning sectors & $\begin{array}{c}\text { Export increase to IBSA } \\
\text { (in per cent) }\end{array}$ \\
\hline Wheat & 2210.47 \\
Sugar & 1204.35 \\
Dairy products & 887.50 \\
Wearing apparel & 413.82 \\
Meat products & 366.67 \\
Bovine meat products & 315.38 \\
Textiles & 292.00 \\
Transport equipment & 247.94 \\
Wood products & 182.50 \\
Electronic equipment & 168.78 \\
Metal products & 154.91 \\
Leather products & 132.13 \\
Machinery and equipment & 126.39 \\
Motor vehicules and parts & 126.37 \\
Metals & 89.30 \\
\hline
\end{tabular}

Table 4.9.1. Sectors in which there is an output reduction for India

\begin{tabular}{lc}
\hline Sector & $\begin{array}{c}\text { Ouput decrease } \\
\text { (in per cent) }\end{array}$ \\
\hline Metals & -8.13 \\
Vegetable oils and fats & -6.89 \\
Coal & -2.20 \\
Oil seeds & -0.82 \\
Motor vehicles and parts & -0.63 \\
\hline
\end{tabular}




\section{South Africa}

South Africa's non-ferrous metals sector records a robust production growth of over 10 per cent on account of an IBSA arrangement. The output of vegetable oils grows by about 1.28 per cent, indicating that South Africa, also gains from India's tariff liberalization in the vegetable oil segment.
The GTAP results confirm apprehensions of India being much more competitive than South Africa in the wearing apparel sector. The wearing apparel sector experienced close to 9 per cent decline in output and demand for unskilled labour. South Africa would also suffer significant output losses in wheat, rice, leather products, electronics and other manufactures.

Table 4.10. South Africa: Output increase

\begin{tabular}{lc}
\hline Winning sectors & $\begin{array}{c}\text { Output increase } \\
\text { (in per cent) }\end{array}$ \\
\hline Metals & 10.43 \\
Vegetable oils and fats & 1.28 \\
Wool, silk-worm cocoons & 1.21 \\
Coal & 0.63 \\
Minerals & 0.49 \\
Electricity & 0.28 \\
Chemical, rubber, plastic products & 0.22 \\
\hline
\end{tabular}

Table 4.11. South Africa: Export increase to IBSA (in per cent)

\begin{tabular}{lc}
\hline Winning sectors & Percentage change \\
\hline Sugar & 1183.33 \\
Vegetable oils and fats & 867.34 \\
Wool, silk-worm cocoons & 358.56 \\
Bovine meat products & 305.56 \\
Meat products & 300.00 \\
Coal & 280.48 \\
Food products & 231.37 \\
Wearing apparel & 200.00 \\
Metal products & 184.19 \\
Manufactures & 170.10 \\
Textiles & 168.83 \\
Machinery and equipment & 165.98 \\
Vegetables, fruit, nuts & 155.29 \\
Leather products & 155.15 \\
Motor vehicules and parts & 151.81 \\
\hline
\end{tabular}


Table 4.11.1. Sectors in which there is an output reduction for South Africa

\begin{tabular}{lc}
\hline Sector & $\begin{array}{c}\text { Percentage change } \\
\text { in output }\end{array}$ \\
\hline Wearing apparel & -8.86 \\
Manufactures & -6.87 \\
Electronic equipment & -6.50 \\
Leather products & -4.51 \\
Wheat & -3.60 \\
Paddy rice & -3.56 \\
\hline
\end{tabular}

\section{Tariff Revenue Implications}

The concern of revenue loss is one which is often raised by finance or revenue ministries of countries that are about to enter FTAs. This concern is legitimate given that Customs' duty collections still form a significant proportion of total revenue collections in developing countries (though its importance has come down over the years).

Using GTAP, in the case of 50 per cent cut in IBSA tariffs it is found that the revenue attributable to IBSA imports ${ }^{8}$ declines by about 21.7 per cent and 11.6 per cent for India and South Africa, respectively. In the case of Brazil it is seen that its revenue attributable from IBSA imports rise by about 6.9 per cent.

The changes in revenue are, however, extremely small in relation to the total Customs revenue collections. In India's case the revenue loss on account of a 50 per cent IBSA FTA is only about $\$ 129$ million, ${ }^{9}$ which is about only 1.1 per cent of total Customs revenue. ${ }^{10}$

\section{From IBSA to IMSA (India- Mercosur-South African Customs Union)}

As Brazil and South Africa are members of two major regional trade arrangements. Brazil is a member of
Mercosur and South Africa is a member of the SACU custom union. Both Mercosur and SACU are highly integrated customs unions. There is a strong legal, political and economic imperative for their inclusion in IBSA, which could well see IBSA changing to IMSA (India-Mercosur - SACU).

It would be useful to see whether the IMSA arrangement would have substantially different effects for India, Brazil and South Africa in comparison to the pure IBSA arrangement. In order to do this the IBSA GTAP simulations were re-run as IMSA suimulations by including other Mercosur countries and other SACU countries.

The GTAP results show that India and South Africa expand their gains in IMSA. India and South Africa, see improved welfare, output and unskilled labour demand. The improved gains to India and South Africa are inter alia due to the addition of a large market - the rest of Mercosur that consists of Argentina, Paraguay and Uruguay. Brazil appears to make only limited gains when it gets additional access to the other SACU countries - Botswana, Lesotho, Namibia and Swaziland. In fact Brazil sees reduction in gains in all parameters. This is largely because, in the IMSA scenario Brazil will need share its market access to IBSA with Argentina, which is as competitive as Brazil in products which have high trade potential in IBSA, e.g., soyabean oil.

\footnotetext{
8 Not total customs revenue from all imports from the world.

9 The equivalent of Rs. 545 Crores.

${ }^{10}$ Using 2004 Year Imports and 2005-2006 tariffs as the basis for calculation.
} 


\section{b. Partial equilibrium simulations}

The Computable General Equilibrium (CGE) results of post-IBSA FTA formation on trade and output can be supplemented by partial equilibrium simulations that would allow a further disaggregation and additional insights on the actual products most likely to be affected by liberalization.

However, unlike the CGE models, the partial equilibrium tend to understate the impact of liberalization, due to the so called "zero initial trade flow" problem. If trade volumes in the base period are close to zero, for example as a consequence of prohibitive trade barriers, they will not be able to fully reflect the importance of liberalization. In other words, in the absence of trade in the current period (a situation present more often in a partial equilibrium model using highly disaggregated trade data), there will likely be no or little trade impact of reducing tariffs - even if that reduction is very large. ${ }^{11}$

With these caveats in mind, the UNCTAD SMART model was used to simulate various IBSA scenarios.

A number of interesting results were obtained. The partial equilibrium simulations obtained using the UNCTAD SMART model could indicate, for instance, potential "key" products to be included as an "early harvest" in the IBSA FTA negotiations. In the case of India, for example, one could define as "key" products those products with an initial import level above 100,000 and where estimated import increases are above 10 per cent. According to this rather loose definition, there are 28 products at HS- 6 digit (19 products at HS-2 digit) that qualify for this status, with a greater concentration in HS chapters 15 (sunflower oil, soya bean oil, etc.) and 72 (flat-rolled stainless steel, ferro-alloys, etc.), but also cane sugar and ethanol.

Similarly, there are 65 HS-6 digit (26 HS-2 digit) "key" products that would provide major gains if liberalization is undertaken by Brazil, such as apparel and clothing (almost half of the products), cotton fabrics, base metal tools and transmission belts, etc.

In the case of South Africa's liberalization schedule, there are some 112 "key" products that provide additional export opportunities for Brazilian or Indian exporters, such a large variety of textile and clothing (cotton yarn, woven fabrics, synthetic yarn, knitted and woven apparel, etc), carpets, bedlinen, curtains, footwear, plaster, rubber products, leather products, but also hand tools, motor vehicles and vehicle parts.

Another important result from the SMART simulation is the impact of the proposed IBSA on non-members. Under a 100 per cent liberalization scenario, the most affected third-countries in the Indian market are Switzerland, United Arab Emirates, Australia, and to a lesser extent the United States, EU, China and Morocco. However, the "good news" is that IBSA will have a considerable net trade creation effect, which means that it is a win-win for IBSA partners and improves global welfare.

\section{Trade in services liberalization}

Liberalization of intra-IBSA services is another promising area of cooperation. Services trade can benefit all IBSA countries, as well as their custom union partners in SACU and MERCOSUR. The issues to be addressed are: if an IBSA economic agreement would incorporate a regime for services trade liberalization among its members, and if so, what its nature would be. In this regard, there are a variety of possible approaches aiming to services trade liberalization. The question is which type of regime would best serve the interests of IBSA countries in this area, and how to make it compatible with other agreements covering services trade in which some IBSA members are already involved, and with WTO requirements for services agreements

\footnotetext{
${ }^{11}$ For a simple methodology allowing this bias to be removed, see Cernat et al. (2003).
} 
as provided by Article V of GATS. Brazil and South Africa are members of agreements covering trade in services. In the case of India the agreement being contemplated with Mauritius incorporates services provisions. Against this background of intra-SACU and MERCOSUR services liberalization, there are different areas that can be explored on which services can be brought into an agreement between India, Brazil and South Africa.

Although SACU does not have a regime for services trade liberalization, SACU members are also members of SADC. In the later case the treaty, as amended in 2001, incorporates services as a core area in which member countries should adopt specific protocols (Article 23) to liberalize their services sectors within the community. On the basis of that article a draft annex on trade in services, setting out the framework for the liberalization of trade in services, has been elaborated. It follows an hybrid GATS approach (positive listing of final commitments, and a liberalization calendar to achieve the level of liberalization committed). The ultimate aim of the liberalization process is that each member will treat the services emanating from other members, and the suppliers of services, in the same way as its own services and services suppliers. All modes of delivery are included. It also contemplates an unconditional MFN clause.

In SADC, the focus has been on six priority sectors, but the aim is to achieve "substantial liberalization" of trade in services by 2015 at the latest. Work is currently underway and SADC member states still need to decide whether the agreement on services will be a stand-alone protocol or an annex to the protocol on trade. Besides the annex on trade in services, there are a number of important related protocols under the SADC Treaty, e.g. protocol on the facilitation of movement of persons; protocol on transport, communications and meteorology; protocol on energy; protocol on education and training; protocol on culture, information and sports; and a proposed protocol on finance and investment (Nkululenko Khumalo, 2006).

The agreement between South Africa and the European Community will also cover the liberalization of trade in services and the free movement of capital (Article 5.3) The parties have agreed to endeavour to extend the scope of the agreement with a view to further liberalize trade in services between them. Recommendations have to be made in this regard, and a first examination of this issue shall take place five years from the entry into force of the agreement. Therefore, currently there are no commitments assumed yet in this regard, but the substantial liberalization of services trade is an explicit objective of the agreement.

In the case of MERCOSUR trade in services is covered by the Montevideo Protocol on Trade in Services of 15 December 1997. The Protocol entered into force on December 2005 after ratification by three of the members (Paraguay has yet to ratify the protocol). The protocol adopts a GATS approach to services trade liberalization (positive lists). Six rounds of negotiations have taken place since the protocol was adopted; MERCOSUR members have incorporated further liberalization commitments in the national lists. The last round concluded on July 2006. All those commitments adopted before the entry into force of the Protocol became binding once the protocol entered into force. The aim is to achieve full liberalization of trade in services by 2010. Significant commitments were adopted by MERCOSUR members after the six rounds of negotiations.

In the case of MERCOSUR, besides the basic protocol there are more than 30 instruments dealing with different services sectors. Also, there is the "MERCOSUR VISA" establishing the regime for the free movement of persons, covering managers, executive directors, administrators, directors, delegates, legal representatives, scientists, researchers, teachers, artists, athletes, newsreaders, along with other 
highly qualified personnel, specialists and professionals. ${ }^{12}$ The agreement being negotiated by MERCOSUR with the European Community, if and when it is finalized, will incorporate provisions leading to services trade liberalization.

An objective of IBSA could be aiming at convergence of the regimes for services trade liberalization and assuring their compatibility when adopting a regime in the agreement that will facilitate trade in such a way that it would not infringe on the regional regimes, but at the same time provide for a level playing field for IBSA operators. This will require first an in-depth review of existing initiatives in the three countries and the negotiations and commitments adopted with third parties. The treatment of the MFN clause would be crucial in this respect. Also, a review of the sectoral provisions could be appropriate to assess the extent to which those could be incorporated into an agreement building on national experiences.

In the field of cooperation and liberalization of trade in services some areas that would be worth exploring in IBSA are listed. First, a regime for the movement of persons. The MERCOSUR Protocol, and the assessment of other mechanism put in place in South-South and North-South agreements, could serve as a good starting point for efforts aimed at the liberalization of movement of natural persons between countries. This is not only necessary for trade in services, but would also facilitate measures for overall investment and trade. Secondly a regime for the recognition of accreditations and qualifications would enhance the potential for services trade creation among IBSA members. A review of the work done in SADC and MERCOSUR in this respect could be helpful to assess the type of mechanism that best serve the interests of all parties. Finally, the issue of government procurement of services could be analysed. The public sector and public enterprises are important sources of demand for many services. Access to such markets would help promote trade in services among IBSA members, and would imply a real preference for members due to the fact that government procurement is currently not covered by the GATS.

\section{Beyond the border issues}

In today's trading environment, border issues have become less relevant when compared with other "behind the border" factors that can have a more significant impact on the overall liberalization effect. In recent years, both multilateralism and regionalism evolved to steps towards integration that go beyond tariffs or nontariff border measures. Deep integration, defined as 'beyond the border measures' (Lawrence, 1996; Mikesell, 1963), is becoming an essential feature of both globalization and regionalization, and has tempered our understanding of regionalism. Regionalism has moved far beyond pure trade/tariff or market integration in the form of free trade areas or Customs unions. Integration has now become much more deeper, much more multifaceted and multisectoral, encompassing a wide range of economic and other political objectives (Bora and Findlay, 1996; Whalley, 1996). New RTAs place considerable emphasis on liberalization of services, investments and labour markets, government procurement, strengthening of technological and scientific cooperation, environment, common competition policies or monetary and financial integration.

Apart from a number of obvious trade policy instruments that have been used for protectionist purposes both at multilateral and regional level (such as antidumping, safeguard measures, countervailing duties, technical barriers to trade, customs procedures and rules of origin), recent RTAs also cover a number of trade-related issues such as investment, competition policy and labour mobility. Lastly, dispute settlement procedures also merit special attention.

${ }^{12}$ MERCOSUR Decision 16/03. 


\section{Rules of origin}

The removal of tariff and non-tariff barriers is a necessary, but not a sufficient condition for the expansion of intraregional trade. As pointed out in the literature, it is crucially important to have appropriate rules of origin to stimulate intraregional investment and production. Rules of origin (RoO) can be designed as protectionist devices, or as a "made in IBSA" instrument. IBSA producers need RoO that could enable them to use both intra-regional and extraregional intermediate inputs so as to produce a quality product at international standards, in order to compete with extraregional goods. ${ }^{13}$

The RoO currently applied by IBSA countries in the context of their own regional integration schemes could form the basis for the RoO which is applied to the new IBSA agreement. In a future IBSA FTA, there can be common rules of origin or sector-specific rules, or a combination of both. The major requirement is that goods containing foreign inputs will qualify as "originating" if they undergo a substantial transformation in FTA countries. Complicated rules tend to limit trade. Simple rules are thus preferable. Generally, the rules of origin should also be less restrictive (and thus more realistic) in terms of say requirements for local content at a level which can be met by most of the national manufacturing industries. Consideration should be give to allowing for full cumulation within MERCOSUR and SADC, as well as SAPTA so that the entire groupings are treated as a single territory for purposes of origin regarding products produced and trade within the region. Thus, for example, the IBSA FTA may require a 40 per cent local content either on a single country basis or on basis of cumulation within MERCOSUR (in case of Brazil), or SACU (in case of South Africa), or SAPTA (in case of India). In addition, the elaboration of the IBSA FTA rules of origins needs to take into account the rules of origin pertaining currently in MERCOSUR, SACU and SAPTA.

One notable exception to this tendency of complex rules of origin is provided by those rules of origin that provide for cumulation of origin between RTA partners and third countries. IBSA could therefore introduce some elements of cumulation of origin that could, in turn, stimulate regional production network, FDI, intra-industry trade and value-added chains.

\section{Antidumping}

The elimination of antidumping measures in RTAs is an exception rather than a rule. ${ }^{14}$ So far, only three North-North RTAs (EU, EEA and ANZCERTA) and two North-South regional agreements (CanadaChile and Canada-Costa Rica FTA) have eliminated antidumping among participants. In the case of MERCOSUR, the parties have discussed the idea of antidumping, but economic difficulties have confronted the advancement of the agreement.

In the case of developing countries, most South-South RTAs continue to allow the applicability of antidumping on trade among members. Most regional agreements allow the use of antidumping measures among their members according to WTO rules. However, one particular NAFTA provision appears to provide for the exemption of Canada and Mexico from antidumping measures, countervailing duties or even safeguard measures by

\footnotetext{
13 For further details on various forms of cumulation of origin, as well as the overall impact of various RoO regimes on transaction costs, production costs, competitiveness, etc., see for instance Estevadeordal and Suominen (2005).

14 For an interpretation of GATT Article XXIV's requirement that RTAs eliminate 'other restrictive regulations of commerce', see for instance Mavroidis (1997). The crucial question is what regulations of commerce are actually deemed to be restrictive. However, it is argued that antidumping and countervailing duties are simply defensive instruments aimed to reduce the negative impact of other restrictive policies such as dumping or subsidies.
} 
requiring that any NAFTA measure specifically name other NAFTA parties before it applies to them (Kerr, 2001:1174). In other words, unless explicitly mentioned, both Canada and Mexico are by default excluded from such trade measures. (The specificity of antidumping measures relating to individual countries or even firms - is quite different from safeguards that are general in nature). Depending on the depth and scope of tariff liberalization, as well as preferential trade remedy regime sought, IBSA countries could either adopt a traditional WTO approach to antidumping, or follow a preferential consideration regime, exempting or avoiding antidumping actions vis-à-vis each other.

\section{Safeguard measures}

One rationale among developing countries in particular in entering into mixed agreements with their main developed trading partners is to open up these markets to sensitive products by removing tariff peaks or non-tariff barriers. The value of this improved market access is nevertheless reduced by other measures that remain in place among RTA members, especially safeguard measures.

WTO rules recognize that imports, whether fairly or unfairly traded, can sometimes cause such harm to domestic industries that temporary restraints are warranted. And these rules include safeguard provisions for industries that have had substantial injury from imports. Some countries, for example Japan, Korea, India, the United States, European Union, Brazil have repeatedly used safeguards in recent years.
RTAs have dealt with safeguards in a variety of ways. Some RTAs apply the WTO, as well as less stringent rules (CEFTA for instance); others have strengthened their applications (NAFTA, the EU-Mexico FTA); ${ }^{15}$ while few RTAs have abolished safeguards altogether on trade between members. Similarly to the EU on its internal trade, other agreements such as ANZCERTA, the agreement between New Zealand and Singapore on a closer economic partnership (CEP) and MERCOSUR, have eliminated safeguard measures.

There is some disagreement as to whether RTAs under WTO rules should be allowed to apply safeguards, subject to certain conditions, only on non-members. Article 2, paragraph 2, of the Agreement on Safeguards states that safeguards should be applied to imports irrespective of their source. However, a footnote to paragraph 1 of the same article stipulates that "nothing in this Agreement prejudges the interpretation of the relationship between Article XIX and paragraph 8 of Article XXIV of GATT 1994". This issue arose in the Argentina Footwear case. ${ }^{16}$ The crucial issue raised was exactly the relationship between Article XXIV, on one hand, and Article XIX of GATT and Article 2.2 of the Agreement on Safeguards, on the other. ${ }^{17}$ Although the safeguards measures applied by Argentina on non-members only were found to violate the WTO rules, the Appellate Body indicated that no ruling was made on "whether, as a general principle, a member of a customs union can exclude other members of that customs union from the application of a safeguard measure".

A case involving preferential application of safeguards is the US safeguards on steel imports. The US

\footnotetext{
15 Although the general application of safeguards is strengthened under NAFTA, the agreement provides for special safeguards on textile and clothing products.

${ }^{16}$ Argentina - Safeguards Measures on Imports of Footwear, Report of the Panel (WT/DS121/R, 25/06/1999) and Report of the Appelate Body (WT/DS121/AB/R, 14/12/1999).

${ }^{17}$ For a comprehensive discussion of this case, as well as a broader analysis of safeguards and regionalism, see Mathis (2002).
} 
announced that it decided to exclude its RTA partners (Canada, Mexico, Israel and Jordan) and certain developing countries ${ }^{18}$ from the steel safeguard measures. ${ }^{19}$ Under the Canada-Chile Free Trade Agreement (CCFTA) bilateral imports are exempted from safeguard measures, unless these imports contribute importantly to the serious injury of the domestic industry. However, other regional arrangements do not exclude partners from global safeguard measures. Under the EEA for instance, despite the high level of integration, and unlike the US under CUSFTA, the EU did not exclude the EFTA States from the safeguard measures intended to countervail the potential surge in imports as a result of US trade actions.

Against this background, it would be beneficial for IBSA countries to consider a special WTO-compliant mechanism whereby IBSA countries are excluded from the imposition of safeguard measures, unless they account for a large part in the import surge, as part of an FTA.

\section{Technical barriers to trade (TBTs) and standards}

The WTO Agreement on Technical Barriers encourages members to harmonize their technical regulations and use international standards in their trade. However, these provisions are watered down by several escape clauses that can be used in a discretionary manner. One way in which several RTAs, both North-North and South-South types, went beyond the WTO rules was by providing for harmonization of standards and mutual recognition of national standards among
RTA members. This is the case of the EU, EEA and EFTA. One important element in the reduction of the negative impact of TBTs on trade flows consists of mutual recognition of conformity assessment. Such an agreement is sometimes concluded even without the framework of an RTA, as in the case of the agreement between the US and EU.

In other cases, even advanced RTAs maintain technical barriers and cumbersome standards that may act as a barrier to intraregional trade flows, despite enhanced mechanisms for cooperation at regional level. Kerr (1997) brings detailed evidence that, in the case of NAFTA, regional integration is not necessarily a more efficient strategy to eliminate trade-distorting TBTs and health, sanitary and phytosanitary standards on agricultural products.

\section{Trade and transport in IBSA}

Conquering distance is one of the main challenges confronting IBSA. Higher transport costs have a negative impact on trade. However, longer distances may be part of the explanation for less trade for different reasons, and less trade means diseconomies of scale in transport services which in turn leads to higher transport costs (Hoffmann et al, 2001). A recent survey ${ }^{20}$ carried out among Indian traders and manufacturers on their perception about the potential of trade between IBSA countries, singled out transport costs as the single largest factor impeding India's exports to Brazil. One reason for high transport costs is that there are no dedicated cargo vessels on this route. Instead, shipments are sent via Europe and involve more than one operator.

\footnotetext{
${ }^{18}$ In accordance with the Agreement on Safeguards, developing countries accounting for less than 3 per cent of the US imports were also excluded from the safeguard measures.

${ }^{19}$ This exclusion of RTA partners from the applicability of US steel safeguard measures has been challenged by Japan as a violation of the MFN principle (Article I of the GATT 1994 and Article 2.2 of the WTO Agreement on Safeguards) and by Korea as a violation of Article 2,3,4,5 of the WTO Agreement on Safeguards.

${ }^{20}$ Parashar Kulkarni. Field Survey Report: INDIA - South-South Economic Cooperation: Exploring IBSA (IndiaBrazil-South Africa) Initiative. CUTS Centre for International Trade, Economics and Environment.
} 
In addition to higher costs, valuable days are lost in loading and unloading at transhipment ports. Freight costs, though perhaps to a lesser extent, were also expressed as a hindrance for Indian exports to South Africa.

The importance of developing efficient transport linkages between the three economies has been present as a main issue to be addressed by the IBSA initiative since its inception; and air and maritime transport has since then been kept high in the agenda in successive formal trilateral meetings. South Africa and India signed and agreement on merchant shipping on March 2006, encouraging exchange of information for facilitating the flow of goods at sea and strengthening cooperation between the countries fleets. Work is well under way aiming at a maritime transport agreement between IBSA countries which advocates for the creation of a Trilateral Marine Transport Corridor between India, South Africa and Brazil. The implementation of such an agreement will be a welcome development. The development of trans-shipment facilities will also be made a priority to support the trade strategy.

A maritime shipping agreement between India, Brazil and South Africa would also be a welcome development. A recent survey ${ }^{21}$ carried out among Indian traders and manufacturers on their perception about the potential of trade between IBSA countries, singled out transport costs as the single largest factor impeding India's exports to Brazil. Similarly, though perhaps to a lesser extent, freight costs were also expressed as a hindrance for Indian exports to South Africa.

\section{Current maritime transport supply capacities}

Although none of the IBSA countries are seen as major shipping nations, with a combined percentage of just above 2 per cent of the world merchant fleet, Brazil and India belong to the upper group of the 35 most important maritime countries. In terms of available specialized capacity, the fleets of the three countries have experienced major improvements in their structure in the past five years.

However, the actual vessel capacity used for international transport and trade between IBSA partners may be insufficient. A snapshot view taken in August 2006 of liner shipping services ${ }^{22}$ between the three countries' major ports shows that direct connections are currently available between India and South Africa and Brazil and South Africa, but none exist between India and Brazil.

At present, 17 carriers were offering direct services between Brazil and South Africa - a very large majority of which are part of longer route connecting to SouthEast Asia - and 11 shipping lines operate between India and South Africa. In both cases major shipping lines offer services between each pair of countries. In terms of available capacity - measured in twentyfoot container equivalent unit (TEU) - the capacity available between Brazil and South Africa is about nine times larger than the capacity between India and South Africa. For container traffic, Brazil and India have the most important ports, such as Santos serving São Paulo and its region and Jawaharlal Nehru, near Mumbai, which rank among the 40 largest container terminals in the world. South Africa's port in Durban is not far behind in rank 57. For bulk trade all three countries can also count on world class, efficient ports such as Richards Bay in South Africa, Tubarão in Brazil and Mormugao in India.

\footnotetext{
${ }^{21}$ P. Kulkarni, Ibid.

${ }^{22}$ Liner shipping services refer to regular services for the transport of general cargo and containers; they do not include shipping of liquid and dry bulks, usually handled under tailored arrangements such as time or voyage charter shipping services contracts.
} 
These and other available ports would by and large support the current volume of exchange between the three pairs of countries and expected potential increases, considering that intra-trade in IBSA still represents a very small portion of total national foreign trade in each case. Nevertheless, at national level note is to be taken that all of three economies have plans to expand their port capacity to face possible congestions in the near future.

The trade between the three economies has been steadily growing over the past five years. When the balance of trade is considered, Brazil has, over recent years, managed to reach a solid overall trade surplus, despite a small deficit with India in 2005. This is very relevant because imbalances in value usually also translate in physical or volume imbalances in shipping operations. In the case of the three IBSA partner's bilateral trades, imbalances may also be found in the type of goods traded and their corresponding transport modality (containerized versus bulk trade). Imbalances in values and differences in the type of packaging and, consequently, the ships used, make it difficult for shipping operators to organize their journey in the most efficient way, both for themselves as service providers or for their clients, the shippers.

\section{Future transport requirements}

Overall, in all these areas, a policy initiative can be coordinated, relying on best practices across IBSA countries. Each partner has a specific expertise that it could share with its IBSA partners (for instance, India in automation of railways, Brazil in introducing private participation in railways or ports). Leading logistics operators in the three countries could envisage working together on door-to-door solutions. India's maritime training institutes can offer modern maritime training to South African and Brazilian seafarers. Similarly, South Africa's experience of port management can also be extended to the Indian port authority.
Shipping lines in all the three countries could forge a network to exchange experiences in implementing ISPS code.

More specifically, several policy objectives could lead to better transport linkages among IBSA countries:

- Increased volumes of trade: as higher volumes result in lower unit costs;

- Aim for balanced trade flows: large differences in inbound and outbound trade result in so-called "empty returns" and increase the overall cost of the transport operation;

- Ensure available transport capacities: transport supply capacities from terminal and sea shipping operators should be sufficient to absorb potential increases of trade;

- Promote greater competition: higher competition both in shipping services and terminal and port operators may contribute to both higher quality and lower rates.

- Promote port efficiency: higher efficiencies of terminals allow for better turnover of ships;

- Promote long-term arrangements between shippers and carriers: longterm contracts, including regular deliveries of known quantities allow for better planning of the use of transport means and for the negotiation of favourable freight rates.

- Direct services and transhipment arrangements: One obvious improvement for the traffic between India and Brazil would be that shipping lines would offer direct services between major ports in both countries. This would not only simplify, but also probably shorten transit times and eventually reduce transport costs. But this could only happen if and when large and frequent volumes of trade become 
sufficient for sea carriers to establish such routes. Until then and considering the long distance to be travelled, the most likely result is that transhipment facilities and services would be located in the most economically and geographically favourable location. South African ports would be ideally placed from a geographical point of view, but of course other ports in the Indian Ocean could compete in cost efficiency and connectivity to serve this purpose.

- Complementary integrated transport services: Each of the three partners has large domestic logistics operators, such as Container Corporation of India (CONCOR from India), Transnet Limited (in South Africa), or Companhia Vale do Rio Doce (CVRD from Brazil), that could improve current transport supply services by providing point-to-point or door-todoor services.

- Common feeder structure: coordination between feeder services and mainline services could be ensured through a common feeder structure similar to Mediterranean markets where mainline carriers agree to use regional feeders operating as a pool. ${ }^{23}$

- Warehousing facility in South Africa: if the main transshipment operations for the IBSA trade are to be located in Durban or Cape Town in South Africa, this might require arrangements for the development of specific warehousing facilities in South Africa to be used by Indian and Brazilian enterprises for mutual transhipments.

\section{FDI trends and opportunities in $\underline{\text { IBSA }}$}

A free trade agreement between IBSA countries will not only lead to increased trade, but also to increased investment flows, as intra-firm trade and global production networks across IBSA will be promoted. An IBSA-wide investment promotion package may add to the favourable environment already existing in IBSA countries.

In India, FDI inflows have been gaining momentum in recent years. Improved economic and policy conditions in the country, where the GDP growth rate exceeded 8 per cent and the stock market grew by more than 30 per cent in 2005, have led to growing investor confidence. The country has surpassed the US in A.T. Kearney's FDI Confidence Index and is expected to receive FDI inflows of $\$ 7$ billion in 2006. What is more significant from the IBSA perspective is that India has become a net capital exporter with outward FDI expected to be $\$ 11$ billion this year. Its attractiveness has been further enhanced by the continued opening up of the Indian economy to inward FDI; one of the first steps being taken is to open its retail industry by allowing foreign single brand retailers to enter the domestic market. These developments suggest that despite bottlenecks such as inadequate infrastructure, the prospects for the country in attracting FDI, including intra-IBSA FDI in areas such as: infrastructure, manufacturing and services are promising.

\footnotetext{
${ }^{23}$ India-Brazil-South Africa (IBSA) Economic Cooperation: Towards a Comprehensive Economic Partnership and Prabir De, Trade in IBSA Economic Cooperation: The Role of Transport Linkages RIS-DP \# 104 December 2005. Both papers are available at: http://www.ris.org.in/pb26.pdf
} 
Table 5. Trends in FDI inflows to IBSA (\$ millions)

\begin{tabular}{lrrrrrrr}
\hline Country & $\mathbf{1 9 9 0 - 1 9 9 4}$ & $\mathbf{1 9 9 5 - 1 9 9 9}$ & 2000 & $\mathbf{2 0 0 1}$ & $\mathbf{2 0 0 2}$ & $\mathbf{2 0 0 3}$ & $\mathbf{2 0 0 4}$ \\
\cline { 2 - 7 } & \multicolumn{2}{c}{ (Annual average) } & & & & & \\
\hline Brazil & 1519 & 18325 & 32779 & 22457 & 16590 & 10144 & 18146 \\
India & 414 & 2619 & 3585 & 5472 & 5627 & 4585 & 5474 \\
South Africa & 113 & 1588 & 888 & 6789 & 757 & 734 & 799 \\
\hline
\end{tabular}

Source: UNCTAD, World Investment Report 2006.

FDI flows to Brazil reached $\$ 33$ billion in 2000, a historic high, and then declined for three consecutive years; this year it is expected to be around $\$ 17$ billion. Brazil ranks seventh in the FDI Confidence Index and has been open to FDI in key sectors of foreign investor interest ranging from agriculture, minerals and metals, infrastructure and services. Therefore, the opportunities for India and South Africa to invest in these sectors are many and bound to yield high returns.

FDI inflows to South Africa started to rise in the mid-1990s, following the end of apartheid regime. In 2005, South Africa registered the largest FDI inflows in Africa, accounting for one-fifth of the region's total FDI. In the long-run, South Africa will resume being the frontrunner for FDI inflows to the region. The country has a good infrastructure and high living standards, with low cost of entry for FDI, for example, its energy costs are also among the lowest in the world. For IBSA countries, FDI in manufacturing and services in South Africa would be fruitful.

In order to further enhance and create avenues and incentives for intra-IBSA FDI flows, apart from bilateral investment promotion and protection agreement between IBSA partners, consideration could be given to having an IBSA investment promotion and protection agreement. This could take the form of a stand-alone agreement, while following some investment promotion policies included in some South-South RTAs. For example, the Uniform Code on Andean Multinational Enterprises established by Decision 292 of the Commission of the Cartagena Agreement provides for the formation of Andean Multinational Enterprises..$^{24}$ One of the conditions for the creation of such an enterprise is that capital contributions by national investors of two or more member countries must make up more than 60 per cent of the capital of the enterprise. Among the privileges which Decision 292 requires member countries to grant to such enterprises are national treatment with respect to government procurement, export incentives and taxation, the right to participate in economic sectors reserved for national companies, the right to open branches in any member country, and the right of free transfer of funds related to investments. Likewise, the Basic Agreement on the ASEAN Industrial Cooperation Scheme (AICO Scheme) was concluded by members of ASEAN in 1996 to promote joint manufacturing industrial activities between ASEAN-based companies.

\section{$\underline{\text { Trade and competition policies }}$}

Among South-South RTAs, only a few initiatives have a regional institutional framework to deal with competition policies. This is to a large extent due to the fact that, in many developing countries, competition laws and authorities are nonexistent or are underdeveloped. However, all IBSA countries have well established and

\footnotetext{
${ }^{24}$ This initiative resembles the EU initiative on the European Company Statute, which allows companies to be incorporated at European, as opposed to national, level.
} 
functioning competition laws and policies at national level. Furthermore, both MERCOSUR and SACU have the prerequisite provisions in place to promote a regional approach to competition. Therefore, the necessary elements are in place for stronger cooperation on competition issues to ensure that the benefits to be derived from trade and investment liberalization are not nullified by private anticompetitive practices of their own enterprises or those of others.

Fields where closer cooperation among IBSA countries could be beneficial include merger control, fighting against international cartels and abuse of dominance position. The EU-South Africa FTA provides a very interesting template for cooperation on cross-border competition issues that could serve as an input for any subsequent negotiations on the topic.

Another important aspect to be pointed out, given the track record of various competition-related agreements (free trade areas, stand-alone agreements, etc), the most promising avenue for cooperation on competition policies among IBSA countries seem to be an agreement among competition agencies that is "decoupled" from the negotiations related to PTA/FTA formation. ${ }^{25}$ Furthermore, such an agreement could be part of those "beyondthe-border" issues that could be included in any "early harvest" IBSA package.

\section{IBSA FTA: other negotiating challenges}

IBSA countries will have to confront a number of strategic policy issues in the process of negotiating, signing and implementing an eventual IBSA FTA.

First, an IBSA FTA would imply an FTA between two integration groupings and one country, which is MERCOSUR, SACU and India.
MERCOSUR is a Customs union with free trade between Brazil, Argentina, Paraguay, and Uruguay (members) and the application of a common external tariff. Venezuela has also recently joint MERCOSUR. SACU is also a Customs union so goods are traded freely of duties and quotas between South Africa, Botswana, Lesotho, Swaziland, and Namibia (members), and they use the South African tariff as the common external tariff. Thus the IBSA FTA would provide important market access opportunities for India into MERCOSUR and SACU; for Brazil into SACU and India; and for South Africa into MERCOSUR and India. At the same time, it is important to note that in the negotiations of the IBSA FTA, Brazil and South Africa will have to consult and seek the agreement of their respective Customs union partners on any tariff concessions they make as these will entail changes in the respective common external tariffs.

Additionally, IBSA countries are parties in various bilateral, regional and interregional trade agreements, some of which are undergoing further negotiations like the GSTP. Thus each IBSA countries would have to strive to ensure that the IBSA FTA does not undermine their other trade relations. Maintaining such coherence in trade negotiations and agreements requires, inter alia, an enhanced institutional trade negotiating capacity in each country's trade representatives and a strengthened and widely representative national consultative and advisory national process to garner and reflect the views of stakeholders.

Second, concrete trade and welfare benefits are needed for each partner country. In the likelihood that such

\footnotetext{
${ }^{25}$ For a comprehensive overview of more than 140 RTAs containing competition-related provisions, see
} UNCTAD, 2005. 
benefits may be disproportionate (uneven) between the partners, which often arises in RTAs, accompanying measures, such as investment and production agreements, need to be devised to enable more equitable participation in trade. Experience shows that ultimately the private sector and the general population are the expected prime beneficiaries of trade agreements will have to support the trade agreement. A diminution of their support will come about if they perceive that the expected business and welfare gains are not forthcoming or are concentrated in the other partners. This will sow the seeds of dissent and ultimately lead to disagreements with governments over membership in IBSA. Thus, an IBSA FTA needs to be twinned with investmen $\mathrm{t}$ - cum-production agreements to back up the market access agreement and ensure equal benefits from opportunities created. Additionally, affected industries in the three countries would need to adjust to new trading conditions and challenges. Thus, adjustment support for import competing industry in the process of regional market opening is an important consideration for policymaking within each country.

Third, an IBSA FTA would add another trade negotiations challenge and eventually another trade agreement to an already growing panoply and crowded arena of BTAs and RTAs pursued by each IBSA countries, in addition to the multilateral liberalization under the WTO. Also, an IBSA FTA will logically have to pursue deeper trade liberalization, going beyond multilateral concessions, to be commercially meaningful to the partners. This raises the question of whether an IBSA FTA makes sense and is worth pursing. The answer is YES. In today's globalizing and liberalizing world economy, IBSA countries, like others, must continuously strive to become and retain competitiveness, both regionally and internationally, and diversify their production and trade in order to achieve their overarching development goals. These countries need to pursue and maximize development gains from the totality of multilateral, interregional, regional and bilateral trade agreements and negotiations. It makes economic (and business) sense to negotiate and carve out multiple trade deals in support of sustainable growth, development and poverty reduction. The challenge is to ensure coherence among these multiple agreements and, importantly, that they become effective building blocks for development-oriented multilateralism.

Fourth, the removal of tariffs through an FTA must be accompanied by the elimination of non-tariff barriers that affect trade among IBSA partners. NTBs have the effect of nullifying or limiting the value of concessions from tariff liberalization. Hence, decisions need to be taken and firm commitments reached at the outset to eliminate NTBs that have the effect of limiting imports from IBSA members. A major hindrance to NTB removal is the lack of a clear definition and classification of the NTBs. UNCTAD is working to address this lacuna. In general, NTBs could be defined as all quantitative and other regulatory measures that have the effect of limiting/restricting imports. These include prohibitions and quotas, foreign currency allocation practices, and restrictive import/export licensing requirements, preshipment inspection requirements, customs surcharges, state trading arrangements, rules of origin, and restrictive and trade distorting product standard and technical requirements, and sanitary and phytosanitary measures. In this 
regard, the possibility of concluding mutual recognition agreement on standards may be explored.

Fifth, conformity with WTO will be required of the IBSA FTA as IBSA countries, as WTO Members, are obliged to ensure the conformity of their trade policies with existing WTO disciplines. The aim of ensuring WTO compatibility of RTAs, like an IBSA FTA, is a guarantee that these RTAs build on (and not undermine) multilateralism, which offers the widest possible trading opportunities. In this regard, IBSA countries would have to grapple with several issues.

A policy statement of intent that the IBSA FTA will be compatible with WTO disciplines needs to be specifically provided in its legal text. Such a provision is integrated in most of the new-generation RTAs concluded in the post-WTO era.

Immediately following its creation, the IBSA FTA would have to be notified to the WTO for transparency purposes, and for its examination and endorsement of its WTO compatibility. Two options are possible. As a South-South RTA, an IBSA FTA can be notified under the enabling clause and secure an easier endorsement from the WTO Committee on Trade and Development. This is almost automatic. But a note of caution is in order. MERCOSUR was notified under the enabling clause, but third countries requested for its examination to be conducted under both the enabling clause and GATT Article XXIV due to the relative importance of MERCOSUR as a trading block. Such a precedent could mean that a future IBSA FTA may also be subject to similar request for greater scrutiny under GATT Article XXIV conditions. The other option is to notify the FTA under GATT 1994
Article XXIV conditions which is for RTAs involving developed countries, and which are examined by the WTO Committee on Regional Trade Agreements. This Committee, it should be noted, has examined many RTAs, but has not yet adopted any reports on any one of them in terms of approving (or disapproving) their WTO compatibility owing to lack of consensus among members. Thus, the final reports on such RTAs are pending. It is preferable that an IBSA FTA is notified under the enabling clause, if only to secure easy endorsement by WTO. It is also possible that an IBSA FTA maybe notified under GATT 1994 Article XXIV. A precedent has been set wherein an agreement signed by South Africa - namely the SADC Trade Protocol - was notified under GATT Article XXIV.

In the event that the IBSA FTA is notified and examined under GATT Article XXIV conditions, then two key conditions, among others, have to be met: the substantially-all-thetrade (SAT) criteria and the reasonable transition period. On the SAT, the FTA has to cover substantially all the trade which is not specifically defined, but assumed to be in the range of full liberalization of $80-90$ per cent of intra-FTA trade. On the transition period, it should not exceed 10 years except in exceptional circumstances.

Sixth, meeting WTO compatibility conditions for GATT Article XXIV raises a number of substantive trade and economic issues pertaining to the FTA liberalisation process.

One issue will be the timing (speed) and sequencing of trade liberalization. The FTA transition period towards fully free trade has to be 10 years (or less), and beyond that then it has to be justified under exceptional circumstances. Most FTAs have a 10 to 15 (or more) -year timeframe for the 
realization of complete free trade. The strategic considerations for the IBSA FTA is that, in general, the transition period should not be inordinately long as this would encourage members to adopt a slow implementation approach which would not be conducive to trade creation. The transition period also should not be ambitiously short so that members are unable to meet the fast liberalization pace given their differences in terms of industrial development, tariff structures and macroeconomic policies. A faster rate of liberalization could also have deleterious impact on fiscal revenue and local industries. A 10 to 15-year transition period seems reasonable.

Another related issue is the extent of liberalization. The impact of FTAs and of an IBSA FTA is likely to be the greatest when liberalization is substantial in terms of product coverage and depth of preferential margins. Substantial product coverage is being interpreted in terms of both the quantity traded and the value covered. WTO disciplines on RTAs enjoin such substantial liberalization among parties to an RTA. Countries in FTAs have opted for almost total liberalization among members for between 80 to 90 per cent of products traded and leave the remaining 10 to 20 per cent to account for sensitive products which could be excluded, mostly temporarily. In cases where FTA members decide to start with a limited range of products for liberalization, as seems would be the case of IBSA, it needs to be mandated that product coverage would be gradually expanded during the transition period to cover substantially all the trade and efforts undertaken accordingly. To have a comprehensive coverage of trade, IBSA FTA could in future examine the mutual liberalization of the services sector.

The sensitivity of a product determines its inclusion (not or less sensitive) or exclusion (sensitive) in an FTA. Product sensitivity is affected by the extent of dependency of governments on fiscal revenue from customs duties and excise taxes on these products (revenue sensitivity); the contribution of local industry to meeting priority social objectives, such as employment and food security (social sensitivity); and infant industry promotion and import substitution protection (industry sensitivity). Preferably, IBSA countries should avoid maintaining long lists of excluded products. Such lists should be temporary for most products, meaning that they would be reviewed at a certain stage and gradually integrated into the inclusion lists. Permanent exclusion from liberalization should be maintained for only a few of the hype sensitive products.

The determination of tariff liberalization schedules for trade in goods reflects product sensitivity considerations. The schedules of tariff reduction normally include products on which: (1) immediate liberalization could take pace; (2) products in which liberalization would take place gradually over the transition period; (3) products which are temporarily excluded from liberalization but are gradually integrated into the FTA during the transition ("grace") period; and (4) the category of permanently excluded products.

Following notification to the WTO, the IBSA FTA would be examined for its compatibility with the relevant WTO provisions. Under the Doha negotiations a new transparency mechanism on RTAs was agreed in June 2006 for the review and examination of all RTAs. IBSA countries would have to follow the procedures of this mechanism. It introduces procedural rules in respect of early announcement, notification, enhanced transparency, subsequent notification and reporting of RTAs. In particular, the mechanism streamlines the review process of an RTA by requiring that the review be completed within one year following notification and that a single formal meeting be devoted to consider each notified RTA and any additional exchange of information should take place in written form. It also introduces factual presentation by the WTO secretariat in the examination process, and technical support to developing countries. 


\section{Key principles for turning challenges into opportunities}

In pursuing IBSA objectives member countries will need to address a number of issues that could become significant constraints and turn these into opportunities on the basis of certain guiding principles for action.

Given that IBSA has been launched in a context of relative low levels of previous interaction among its members - as measured by different economic indicators related to trade and investment flows - a big push would be needed during this take-off period. At the same time, there are genuine economic complementarities that could provide a solid launching ground for deeper economic integration between its members. This would ensure that they would become "natural" trade and investment partners fully exploiting their synergies. The challenge is how to develop in the short term, a critical mass of business exchanges and demonstrable winners that will provide a support base for the initiative and assure its sustainability in time.

This would require IBSA countries bringing their own experiences on best practices regarding private-public partnerships into an IBSA cooperation context and launch some high profile and viable pilot projects such as solar, wind, biofuels and oilshales energy, forging an IBSA "iron and steel" triangle, collaboration in aerospace industry, and joint research and development projects in high-tech areas such as biotech and nanotechnology, and socially-relevant areas such as medicines and vaccines for tropical diseases and "living technologies" for the poor.

Since a key challenge facing IBSA is how to overcome the physical, cultural and economic distance between its members, it would be imperative to simultaneously seek to bridge these three gaps. The significant progress achieved in bridging the economic distance so far shows that cultural and physical distances can be overcome if there is sufficient economic attraction and vice versa. Geographic and cultural proximity has been highlighted in the literature as factors contributing to successful integration and enhanced cooperation among countries. For instance, countries sharing a common language are estimated to have total trade flows almost twice as large as those between two otherwise similar countries without a common language. This is a non-negligible factor between India and South Africa on one hand, and Brazil on the other and therefore needs to be addressed with due priority. As mentioned elsewhere, closing the language gap through appropriate government-supported cooperation as well as through trade in cultural and educational services would have a major facilitating role in all IBSA initiatives. Similarly, to deal with the magnification of transport and other transaction costs due to the effects of remoteness, the steps that IBSA has already undertaken to address transport issues including for establishing air and maritime corridors between the three countries would need to be implemented urgently.

In order to put behind it the history of relatively less institutionalized and structured cooperation between IBSA countries, bold and accelerated steps would have to be taken including through more ambitious trade liberalization, facilitation, incentive-giving, rule-setting and convergence-building inter-governmental agreements. This requires IBSA policymakers to give high priority to IBSA cooperation and to sustain the current momentum, so as to allow concerned actors and stakeholders to increase mutual understanding and move quickly on the learning curve involved in cooperative undertakings. For instance, deliberate efforts need to be made at policy, industry and firm level, to ensure that a "Made in IBSA" logic will prevail over a zero-sum view of structured trade and investment liberalization among IBSA members. Proceeding from the point of convergence of IBSA-linked PTAs, a leap of faith may be required to move towards deeper, but partial liberalization or even a full liberalization involving an FTA. Against the background of the tripling of intra-IBSA 
trade in the last decade in an MFN scenario, UNCTAD's simulation show that intra-IBSA trade could double on an annual basis in a full liberalization scenario, and this is without taking into account dynamic effects. What is important is that in this scenario all three countries gain in trade creation and the adjustment costs are minimal. The paper identifies a number of core sectors and specific products that could be drivers of this significant trade expansion.

As IBSA countries are themselves hubs of complex regional agreements and engagements, any institutionalized IBSA cooperation will have to carefully maintain the balance between the logic behind IBSA and the geo-economic and political rationale of these other agreements, as well as legal compatibility. More specifically, any IBSA agreement will in fact have to be negotiated and implemented not just by Brazil, but by all MERCOSUR members. Similarly, in the case of South Africa, IBSA will have to involve all SACU members. This in itself represents a rather complex exercise directly involving 11 countries. Furthermore, measures adopted at the IBSA level will have implications for the functioning of the other agreements of which IBSA members are part. Since as our simulations show, including members of Mercosur and SACU will have a net positive effect and will spread the benefits among all concerned members, it should be possible to overcome both the technical and political hurdles.

A way to address some of the potential complicating factors and challenges in institutionalized IBSA cooperation is to adopt a "variable geometry" approach moving ahead in areas and among partners amenable to do so. This would avoid an IBSA process held hostage to moving on the basis of a minimum common denominator, and thus dramatically reducing the benefits to be derived from IBSA efforts. As pointed out in the paper, if the prerequisite conditions are in place, there are number of opportunities and strengths that could provide the necessary initial as well as long- run impetus for IBSA promises to become reality. This would allow accommodation of national sensitivities in the process of tariff liberalization and dismantling. In services, an expression of variable geometry could be differentiated speeds for the bound liberalization of certain sectors in IBSA.

Realism would dictate that achieving an early harvest in those areas possible will contribute to maintaining momentum until such time that bigger steps could be taken for deeper economic integration. For example, in the context of an IMSA-PTA, the immediate elimination of nuisance tariffs would be a step in the right direction. Agreements on dealing with non-tariff barriers especially sanitary and phytosanitary (SPS) and technical barriers to trade (TBT) requirements on goods on a tripartite basis would immediately improve market access conditions for goods trade. Similarly for services, binding of autonomous liberalization undertaken could create a favourable environment for catalyzing IBSA services trade. This would send a positive message to all the stakeholders that the process is for real and is here to stay.

While the bilateral relationships between India-Brazil, India-South-Africa and Brazil-South Africa will be the engines driving IBSA towards the three Cs of IBSA partnership, namely, convergence, cooperation and collaboration, it is equally important that the partnership deliberately seeks to add value and harness the synergies arising from trilaterally-conceived, owned and implemented agreements, undertakings and projects. For instance, it makes sense to negotiate mutual recognition agreements (MRAs) on standards and qualification requirements that impact on goods and services trade in a trilateral context than through three separate bilateral agreements. Apart from economizing on negotiating resources, a trilateral approach is an ideal facilitation tool for administrators, business and consumers in IBSA. 


\section{UNCTAD's role}

The São Paolo Consensus adopted at the UNCTAD XI Conference in 2004 mandated UNCTAD to undertake work on the "new geography of international trade" and South-South cooperation, as well as regionalism. UNCTAD is well placed to support the path-breaking IBSA initiative in interregional South-South cooperation through its research and analysis and technical support, as well as bringing an interregional insights and perspectives on South-South economic integration. UNCTAD databases, analytical tools and current work on strengthening the participation of developing countries in new and dynamic sectors of international trade could help in awareness raising about complementarities and trade and investment opportunities. 
Annex table 1. Existing BTAs and RTAs under negotiation or study

\begin{tabular}{|c|c|c|c|}
\hline \multirow[t]{2}{*}{ IBSA } & \multirow[t]{2}{*}{ Existing trade agreements } & \multicolumn{2}{|c|}{$\begin{array}{l}\text { Trade agreements under negotiation or } \\
\text { study (consideration) }\end{array}$} \\
\hline & & South-South & South-North \\
\hline India & $\begin{array}{l}\text { SAFTA (South-Asian Free Trade } \\
\text { Agreement formed between members of } \\
\text { SAARC, namely Bangladesh, Bhutan, } \\
\text { India, Maldives, Nepal, Pakistan and Sri } \\
\text { Lanka) } \\
\circ \text { BIMSTEC (Bay of Bengal Initiative for } \\
\text { MultiSectoral Technical and Economic } \\
\text { cooperation between Bangladesh, Bhutan, } \\
\text { India, Myanmar, Nepal, Sri Lanka, and } \\
\text { Thailand). } \\
\circ \text { India-Thailand FTA (signed 9 October } \\
\text { 2003) } \\
\circ \text { India-Sri Lanka FTA (signed } 28 \text { December } \\
\text { 1998) } \\
\circ \text { GSTP member. } \\
\circ \text { India-EU Strategic Partnership dialogue } \\
\text { (not FTA). } \\
\circ \text { India-US trade dialogue (not FTA) } \\
\circ \text { India-ASEAN Framework Agreement on } \\
\text { Comprehensive Economic Cooperation. } \\
\circ \text { India-Singapore Comprehensive Economic } \\
\text { Cooperation Agreement } \\
\circ \text { Bangkok Agreement (Bangladesh, China, } \\
\text { India, Republic of Korea, PDR Laos, Sri } \\
\text { Lanka) }\end{array}$ & $\begin{array}{ll}\circ & \text { India-Thailand } \\
\circ & \text { India and Malaysia } \\
\circ & \text { India and Indonesia } \\
\circ & \text { India-SACU } \\
\text { preferential trade } & \text { Agreement } \\
& \text { Andia-MERCOSUR } \\
\circ & \text { India } \\
& \text { preferential trade } \\
\text { agreement } & \\
\circ & \text { India-Chile } \\
& \text { preferential trade } \\
& \text { agreement } \\
\circ & \text { India-Mauritius } \\
& \text { closer economic } \\
& \text { partnership } \\
& \text { agreement } \\
\circ & \text { India-Gulf } \\
& \text { Cooperation } \\
& \text { Council FTA } \\
\circ & \text { India-China } \\
\circ & \text { India-Mongolia } \\
\circ & \text { India-Korea } \\
\circ & \text { IBSA FTA }\end{array}$ & ○ India-Japan \\
\hline Brazil & 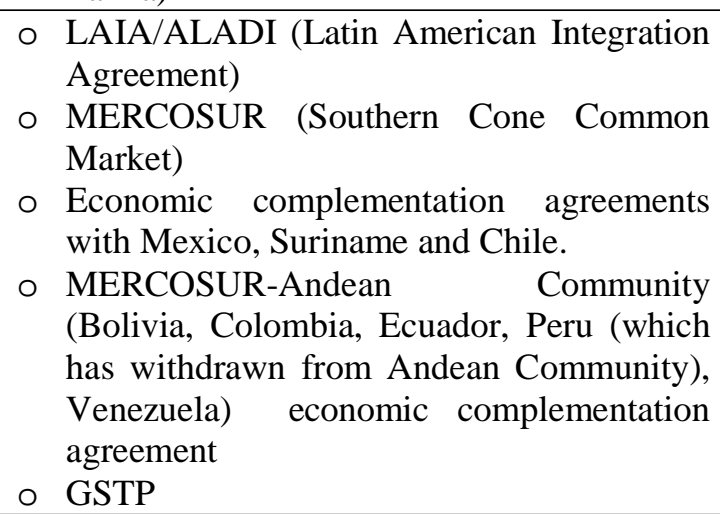 & $\begin{array}{ll}\text { MERCOSUR- } \\
\text { Egypt framework } \\
\text { agreement } \\
\circ \text { MERCOSUR-India } \\
\text { framework } \\
\text { cooperation } \\
\text { agreement } \\
\circ \text { IBSA FTA }\end{array}$ & $\begin{array}{ll}\text { FTAA (Free } \\
\text { Trade Area of } \\
\text { the Americas) } \\
\circ \text { MERCOSUR- } \\
\text { EC } \\
\text { framework } \\
\text { cooperation } \\
\text { agreement }\end{array}$ \\
\hline $\begin{array}{l}\text { South } \\
\text { Africa }\end{array}$ & $\begin{array}{ll}\circ & \text { SADC (Southern African development } \\
\text { Community) } \\
\circ \text { SACU (Southern African Customs Union) } \\
\circ \text { South Africa-EU Trade Development } \\
\text { Cooperation Agreement } \\
\circ \text { Preferential agreements with Malawi, } \\
\text { Zimbabwe and Croatia }\end{array}$ & $\begin{array}{ll}\circ & \text { African Economic } \\
\text { Community } \\
\text { pursued by the } \\
\text { African Union. } \\
\circ \text { IBSA FTA with } \\
\circ \text { FTA } \\
\text { MERCOSUR } \\
\circ \text { FTA with India } \\
\circ \text { FTA with Nigeria } \\
\circ \text { FTA with China } \\
\circ & \text { FTA with } \\
& \text { Singapore } \\
\circ & \text { SACU-India FTA }\end{array}$ & $\begin{array}{l}\text { Observer in } \\
\text { the Economic } \\
\text { Partnership } \\
\text { Agreement } \\
\text { negotiations } \\
\text { between } \\
\text { SADC and } \\
\text { EU } \\
\text { SACU } \\
\text { negotiations } \\
\text { of FTA with } \\
\text { EFTA and } \\
\text { with US }\end{array}$ \\
\hline
\end{tabular}




\section{Bibliography}

Bora, B. and C. Findlay (1996). Regional integration and the Asia-Pacific, Oxford University Press, Melbourne.

Cernat, L., S. Laird, L. Monge-Rofarello and A. Turrini (2003). The EU's Everything But Arms Initiative and the Least-developed Countries, WIDER Discussion Paper No. 2003/47, UNU/WIDER, Helsinki.

Estevadeordal, A. and K. Suominen (2005). "Rules of Origin: A World Map." in Cadot, Olivier, Antoni Estevadeordal, Akiko Suwa-Eisenmann and Thierry Verdier (eds.), TheOrigin of Goods: A Conceptual and Empirical Assessment of Rules of Origin in PTAs. Oxford University Press and CEPR (forthcoming).

Hoffmann, J., P. Isa and G. Perez (2001). Trade and Maritime Transport Between Africa and South America, ECLAC, Santiago, Chile.

Kerr, W. (1997). 'Removing Health, Sanitary and Technical Non-Tariff Barriers in NAFTA', Journal of World Trade 31:5: 57-73.

Kerr, W. (2001). ‘Greener Multilateral Pastures for Canada and Mexico: Dispute Settlement in the North American Free Trade Agreements', Journal of World Trade. 35(6): 1169-80.

Lawrence, R. (1996). Regionalism, Multilateralism, and Deeper Integration, Washington, DC: The Brookings Institution.

Mathis, J. (2002). Regional Trade Agreements in the GATT/WTO: Article XXIV and the Internal Trade Requirement, The Hague: TMC Asser Press.

Mavroidis, P. (1997). 'Comments', in P. Demaret et al. (eds.) Regionalism and Multilateralism after the Uruguay Round, European Interuniversity Press, Brussels, pp.389-96.

Mikesell, R.F. (1963). 'The theory of common markets as applied to regional arrangements among developing countries' in International trade theory in a developing world: Proceedings of a conference held by the International Economic Association, eds. R. Harrod and D. Hague, New York: St. Martin's Press, Inc.

Nkululenko Khumalo (2006). “Implementation of SADC Protocols Affecting Trade in Services", UNCTAD (forthcoming).

Soko, M. (2006). "Report on a Field Survey for South-South Trade and Investment Co-operation Project: Exploring the IBSA Initiative", South African Institute of International Affairs, Trade Policy Report 12, April.

UNCTAD (2005). Competition Provisions in Regional Trade Agreements: How to Assure Development Gains, UNCTAD/DITC/CLP/2005/1.

UNCTAD (2006). The Emerging Biofuels Market: Regulatory, Trade and Development Implications, UNCTAD/DITC/TED/2006/4, forthcoming.

Whalley, J. (1996). 'Why do countries seek regional trade agreements?', NBER Working Paper no. 5552. 
UNCTAD Study Series on

\section{POLICY ISSUES IN INTERNATIONAL TRADE AND COMMODITIES}

No. 1 Erich Supper, Is there effectively a level playing field for developing country exports?, 2001, 138 p. Sales No. E.00.II.D.22.

No. 2 Arvind Panagariya, E-commerce, WTO and developing countries, 2000, 24 p. Sales No. E.00.II.D.23.

No. 3 Joseph Francois, Assessing the results of general equilibrium studies of multilateral trade negotiations, 2000, 26 p. Sales No. E.00.II.D.24.

No. 4 John Whalley, What can the developing countries infer from the Uruguay Round models for future negotiations?, 2000, 29 p. Sales No. E.00.II.D.25.

No. 5 Susan Teltscher, Tariffs, taxes and electronic commerce: Revenue implications for developing countries, 2000, 57 p. Sales No. E.00.II.D.36.

No. 6 Bijit Bora, Peter J. Lloyd, Mari Pangestu, Industrial policy and the WTO, 2000, 47 p. Sales No. E.00.II.D.26.

No. 7 Emilio J. Medina-Smith, Is the export-led growth hypothesis valid for developing countries? A case study of Costa Rica, 2001, 49 p. Sales No. E.01.II.D.8.

No. 8 Christopher Findlay, Service sector reform and development strategies: Issues and research priorities, 2001, 24 p. Sales No. E.01.II.D.7.

No. 9 Inge Nora Neufeld, Anti-dumping and countervailing procedures - Use or abuse? Implications for developing countries, 2001, 33 p. Sales No. E.01.II.D.6.

No. 10 Robert Scollay, Regional trade agreements and developing countries: The case of the Pacific Islands' proposed free trade agreement, 2001, 45 p. Sales No. E.01.II.D.16.

No. 11 Robert Scollay and John Gilbert, An integrated approach to agricultural trade and development issues: Exploring the welfare and distribution issues, 2001, 43 p. Sales No. E.01.II.D.15.

No. 12 Marc Bacchetta and Bijit Bora, Post-Uruguay round market access barriers for industrial products, 2001, 50 p. Sales No. E.01.II.D.23.

No. 13 Bijit Bora and Inge Nora Neufeld, Tariffs and the East Asian financial crisis, 2001, 30 p. Sales No. E.01.II.D.27. 
No. 14 Bijit Bora, Lucian Cernat, Alessandro Turrini, Duty and quota-free access for LDCs: Further evidence from CGE modelling, 2002, 130 p. Sales No. E.01.II.D.22.

No. 15 Bijit Bora, John Gilbert, Robert Scollay, Assessing regional trading arrangements in the Asia-Pacific, 2001, 29 p. Sales No. E.01.II.D.21.

No. 16 Lucian Cernat, Assessing regional trade arrangements: Are South-South RTAs more trade diverting?, 2001, 24 p. Sales No. E.01.II.D.32.

No. 17 Bijit Bora, Trade related investment measures and the WTO: 1995-2001, 2002.

No. 18 Bijit Bora, Aki Kuwahara, Sam Laird, Quantification of non-tariff measures, 2002, 42 p. Sales No. E.02.II.D.8.

No. 19 Greg McGuire, Trade in services - Market access opportunities and the benefits of liberalization for developing economies, 2002, 45 p. Sales No. E.02.II.D.9.

No. 20 Alessandro Turrini, International trade and labour market performance: Major findings and open questions, 2002, 30 p. Sales No. E.02.II.D.10.

No. 21 Lucian Cernat, Assessing south-south regional integration: Same issues, many metrics, 2003, 32 p. Sales No. E.02.II.D.11.

No. 22 Kym Anderson, Agriculture, trade reform and poverty reduction: Implications for Sub-Saharan Africa, 2004, 30 p. Sales No. E.04.II.D.5.

No. 23 Ralf Peters and David Vanzetti, Shifting sands: Searching for a compromise in the WTO negotiations on agriculture, 2004, 46 p. Sales No. E.04.II.D.4.

No. 24 Ralf Peters and David Vanzetti, User manual and handbook on Agricultural Trade Policy Simulation Model (ATPSM), 2004, 45 p. Sales No. E.04.II.D.3.

No. 25 Khalil Rahman, Crawling out of snake pit: Special and differential treatment and post-Cancun imperatives, 2004.

No. 26 Marco Fugazza, Export performance and its determinants: Supply and demand constraints, 2004, 57 p. Sales No. E.04.II.D.20.

No. 27 Luis Abugattas, Swimming in the spaghetti bowl: Challenges for developing countries under the "New Regionalism", 2004, 30 p. Sales No. E.04.II.D.38.

No. 28 David Vanzetti, Greg McGuire and Prabowo, Trade policy at the crossroads The Indonesian story, 2005, 40 p. Sales No. E.04.II.D.40.

No. 29 Simonetta Zarrilli, International trade in GMOs and GM products: National and multilateral legal frameworks, 2005, 57 p. Sales No. E.04.II.D.41. 
No. 30 Sam Laird, David Vanzetti and Santiago Fernández de Córdoba, Smoke and mirrors: Making sense of the WTO industrial tariff negotiations, 2006, Sales No. E.05.II.D.16.

No. 31 David Vanzetti, Santiago Fernandez de Córdoba and Veronica Chau, Banana split: How EU policies divide global producers, 2005, 27 p. Sales No. E.05.II.D.17.

No. 32 Ralf Peters, Roadblock to reform: The persistence of agricultural export subsidies, 2006, 43 p. Sales No. E.05.II.D.18.

No. 33 Marco Fugazza and David Vanzetti, A South-South survival strategy: The potential for trade among developing countries, 2006, $25 \mathrm{p}$.

No. 34 Andrew Cornford, The global implementation of Basel II: Prospects and outstanding problems, 2006, $30 \mathrm{p}$.

No. 35 Lakshmi Puri, IBSA: An emerging trinity in the new geography of international trade, $2007,50 \mathrm{p}$.

United Nations publications may be obtained from bookstores and distributors throughout the world. Please consult your bookstore or write to:

\section{United Nations Publications}

All orders from North America, Latin America, the Caribbean and Asia and the Pacific should be sent to:

United Nations Publications

Room DC2-853, 2 UN Plaza

New York, NY 10017, USA

Telephone: (212) 963-8302, Toll Free 1-800-253-9646 (North America only)

Fax: (212) 963-3489

E-mail: publications@un.org

Customers in Europe, Africa and the Middle East should send their orders to:

Section des Ventes et Commercialisation

Bureau E-4, CH-1211

Geneva 10, Switzerland

Telephone: 41 (22) 917-2613/2614

Fax: 41 (22) 917-0027

E-mail: unpubli@unog.ch 



\title{
QUESTIONNAIRE \\ UNCTAD Study Series on \\ POLICY ISSUES IN INTERNATIONAL TRADE \\ AND COMMODITIES
}

(Study series no. 35: IBSA: An emerging trinity

in the new geography of international trade)

Readership Survey

Since 1999, the Trade Analysis Branch of the Division on International Trade in Goods and Services, and Commodities of UNCTAD has been carrying out policy-oriented analytical work aimed at improving the understanding of current and emerging issues in international trade of concern to developing countries. In order to improve the quality of the work of the Branch, it would be useful to receive the views of readers on this and other similar publications. It would therefore be greatly appreciated if you could complete the following questionnaire and return to:

\author{
Trade Analysis Branch \\ DITC, Rm. E-8076 \\ United Nations Conference on Trade and Development \\ Palais des Nations \\ CH-1211 Geneva 10, Switzerland
}

1. Name and address of respondent (optional):

2. Which of the following describes your area of work?

Government

Private enterprise institution

International organization

Not-for-profit organization
Public enterprise

Academic or research

Media

Other (specify)

3. In which country do you work?

4. $\quad$ Did you find this publication $\quad \square$ Very useful $\square$ Of some use $\square$ Little use to your work?

5. What is your assessment of the contents of this publication?

$\square$ Excellent $\square$ Good $\square$ Adequate $\quad \square$ Poor

6. Other comments: 